\title{
Shear strength of dry tills from the southern half of Norway in relation to bedrock geology
}

\author{
Øystein Lid Opsal'
}

\author{
${ }^{1}$ Department of Geoscience and Petroleum, Norwegian University of Science and Technology, Sem Scelands veg 1, 7491, Trondheim, Norway. \\ E-mail corresponding author (Øystein Lid Opsal): oystein.opsal@ntnu.no
}

Till is the dominant Quaternary sediment in Norway, where the till deposits mostly originate from local rocks with a transport distance less than five kilometres. Debris slides and flows are among the main geohazards on till-covered valley slopes, and in this context the shear strength of Norwegian tills is poorly studied. Therefore, a set of 33 near-surface, genetically independent till samples were collected from various locations in the southern half of Norway to investigate the shear strength and its relation to bedrock geology. The disturbed samples were sieved $(<16 \mathrm{~mm})$ and dried before they were tested in a large-scale direct shear box apparatus at normal stresses of 100, 200 and $300 \mathrm{kPa}$, and with a shear rate of $2.0 \mathrm{~mm} / \mathrm{min}$ for approximately $40.0 \mathrm{~mm}$ horizontal displacement. Overall, the result regarding the average 'initial dry testing density' was 1.67 $\mathrm{g} / \mathrm{cm}^{3}$, while the maximum shear stresses for the given normal stresses on average were $84.9 \mathrm{kPa}, 163.2 \mathrm{kPa}$ and $243.7 \mathrm{kPa}$, respectively. The average angle of friction and cohesion were $38.4^{\circ}$ and $5.3 \mathrm{kPa}$. Furthermore, the samples were categorised into six regional rock provinces. The mapped rock type assumed to represent the origin of the till samples were based on their area of extent around the sample sites, and adjusted for by the late-Weichselian ice-flow directions. On average, the 'Precambrian basement' province locally affected by the Caledonian orogeny (mainly gneisses) had the highest angle of friction. In comparison, the 'Caledonian' province of overthrust sheets of sandstone and schist (mainly sandstones) had the lowest angle of friction. Although not conclusive, this study provides indications of a relationship between till shear strength and bedrock geology, suggesting that some provinces may, solely on the basis of their associated geological parameters, be more prone to debris slides and flows than others.

Keywords: till, shear box, shear strength, bedrock geology, landslide

Received 1. December 2016 / Accepted 25. August 2017 / Published online 23. October 2017

\section{Introduction}

The Norwegian bedrock geology is highly variable, both in terms of formation (igneous, metamorphic and sedimentary) as well as age, ranging from Precambrian to Permian (Johnsen, 1995). In addition to the Precambrian 'Basement', Caledonian rocks comprising overthrust sheets of both Precambrian rocks and sandstone and schist, metamorphic and igneous rocks, as well as Precambrian basement locally affected by the Caledonian orogeny, constitute the main part of the Norwegian bedrock (Geological Survey of Norway [NGU], 2016a). Regarding the formation of till, Boulton
(1974) stated that the processes of crushing, plucking and abrasion of rock masses depend largely on rock strength and hardness. The variation of the rocks also affects the composition of till, as it is normally composed of local rock material (Låg, 1948; Dreimanis et al., 1957). Due to the several ice ages (Vorren \& Mangerud, 2006), till is regarded as the dominant Quaternary sediment in Norway (Bergersen \& Garnes, 1972; Garnes, 1973; Haldorsen et al., 1983). For onshore areas, almost all Quaternary deposits are younger than $300 \mathrm{ka}$, and probably more than $90 \%$ of the present, remaining glacial deposits derive from the Weichselian glaciation, i.e., younger than $115 \mathrm{ka}$ (Olsen et al., 2013).

Opsal, Ø.L. 2017: Shear strength of dry tills from the southern half of Norway in relation to bedrock geology. Norwegian Journal of Geology 97 ,

145-169. https://dx.doi.org/10.17850/njg97-2-04. 
While the till cover in higher relief areas is mostly discontinuous and its thickness only locally exceeds two metres (Haldorsen \& Krüger, 1990), a consistent layer of till is covering about $25 \%$ of the Norwegian mainland area (Thoresen, 2000; Olsen et al., 2013). Even though the transport distances of till may be several tens of kilometres (Clark, 1987), or even hundreds of kilometres (Dreimanis \& Vagners, 1971), most of the Norwegian till material has been transported a relatively short distance, i.e., less than five kilometres (Reite, 1990; Thoresen, 2000). Studies done in the neighbouring Scandinavian countries, Sweden and Finland, have found similar results, concluding that the majority of tills are transported only a few kilometres (Perttunen, 1977).

In geotechnical aspects, till is generally regarded as a 'good' foundation soil (Milligan, 1976), although the shearing resistance is essential in the analysis of soil stability problems such as slope stability (Fredlund \& Rahardjo, 1993; Allred, 2000; Das, 2010). When excluding floods, it is primarily slope stability issues, such as avalanches and landslides, which count for the main geohazards in Norway. Historically, landslides and avalanches in snow, rock and clay are the main causes of fatalities (Jaedicke et al., 2008), but even though debris slides and flows seldom result in human fatalities, they often cause damage to buildings and infrastructure. Valley slopes that are mostly covered in till are, consequently, most prone to such landslides (Bargel et al., 2011). Furthermore, due to the predicted future climate change, the frequency of debris slides and flows in Norway is expected to increase (Kronholm et al., 2007; Norem \& Sandersen, 2014; Sandersen, 2014).

The Norwegian Water Resources and Energy Directorate (NVE) holds the overall responsibility for governmental management tasks regarding the prevention of accidents due to landslides (NVE, 2016). Additionally, the NVE, in cooperation with the Norwegian Public Roads Administration, the Norwegian Meteorological Institute, and the Norwegian National Rail Administration, regularly publish online national forecasts of debris-slide warnings (NVE, 2013). This warning system is based on the correlation between past landslide incidents and both meteorological and hydrological variables (Boje et al., 2014), thus not directly including parameters such as shear strength. Concerning the present and future potential of debris slides and flows in Norwegian valleys, as well as the geological limitations of the national warning system, it is of special interest for NVE to investigate the shear strength in a variety of tills, thereby resulting in the motivation for this project.

Regarding slope stability, the soil mass shear strength can be defined as the internal resistance per unit area that the soil mass can offer to resist failure and sliding along any plane inside it' (Das, 2010, p. 365). Controlled shear tests have been a method to measure the shear strength of soils since the 1930s (Bishop \& Eldin, 1950). However, as also indicated by Thermann et al. (2006), it seems that homogeneous soils consisting of one or a few closely related fractions such as clay, as well as non-cohesive soils, such as sand, have been the most commonly used material for shear strength tests (e.g., Donald, 1956; Bjerrum \& Landva, 1966; Palmeira, 1987; Yagiz, 2001; Miller \& Hamid, 2007; Schnellmann et al., 2013). In comparison, it seems that fewer studies have been done on heterogeneous soils consisting of multiple fractions such as till or colluvium (e.g., Gan et al., 1988; Iverson et al., 1994; Vanapalli et al., 1996; Fannin et al., 2005; Thermann et al., 2006). Apart from limited and local studies such as construction project reports and master theses (e.g., Lund, 2013; Langåker, 2014; Langeland, 2016), the shear strength of Norwegian tills is rather poorly documented.

For cohesionless materials, the shear strength is usually expressed in terms of the so-called angle of internal friction. On this matter, the shear stress-deformation relations are largely influenced by the initial soil density. For densely packed soils, this is visualised by a significant peak in the shear stress-deformation curve due to dilatancy, before levelling out horizontally in an 'ultimate steady state condition'. In contrast, loose to medium-packed soils show either no peak or only a minor peak in the curve before reaching the ultimate, horizontal level (Kaniraj, 1988; Ishibashi \& Hazarika, 2015). According to Simoni \& Houlsby (2006), this critical (ultimate) shear strength represents the minimum shear strength that the soil can display in a shear test. Furthermore, geological parameters, such as particle size distribution and particle shape (Cornforth, 1973; Yagiz, 2001), as well as particle roughness and strength (Duncan et al., 2014), are known to have an effect on soil shear strength. Mineralogy is also known to influence soil shear strength (Fannin et al., 2005), and the critical state angle of shearing resistance is, according to Bolton (1986), principally a function of mineralogy. Therefore, since till largely originates from local rocks, differences in bedrock geology should to some extent also influence till shear strength, and, consequently, there should be some noticeable differences among different rock types and provinces.

Typically, the upper parts and surfaces of Norwegian till deposits are more porous than the underlying, consolidated till due to processes such as weathering and biological activity (Norem \& Sandersen, 2014; Sandersen, 2014), which, in turn, may reduce the relative soil density (Dearman, 1991). Debris slides and flows are usually triggered in this upper and weathered part of the deposits (Sandersen, 2014). Rather than finding the maximum peak shear strength, which is more likely occurring in the underlying, relatively non-weathered and densely packed till, this study focuses on the critical shear strength of the upper, loose to medium-packed surface till. 
Hence, this study presents results of the critical shear strength for 33 tills from various locations in the southern half of Norway, i.e., south of and including Nord-Trøndelag county (Fig. 1; Table $1 \& 2$ ). The study examines the test results with regard to the mapped bedrock geology, i.e., the samples are geographically divided into regional, major rock provinces and then further into rock types. This categorisation of samples into rock provinces is done for the purpose of displaying both internal differences and similarities, as well as to evaluate the relation between till shear strength and regional bedrock geology and the various associated rock types. Additionally, to distinguish between samples and provinces of presumably 'strong rocks' and 'weak rocks', brief descriptions of the typical compressive strengths of the dominating rock types of each province are included for an evaluation of this potential relation to the shear test results. In summary, the aim of the study is to investigate the potential relation of till shear strength to bedrock geology, and evaluate if some provinces in the southern half of Norway may be more prone to debris slides and flows than others on the basis of bedrock geology and associated geological parameters. However, it must be emphasised that the aim of the study is not to replicate current individual field conditions regarding e.g., stress conditions, density and saturation for the sake of retrieving the actual, in situ shear strength, but to test different tills under equal test settings to show the differences and for the purpose of a comparative analysis. Due to the limited documentation of previous, comparable, Norwegian studies on till shear strength, the sampling and testing procedure are tailored for this study, and are therefore described in detail. Note that this is the first introductory article of the study, whereas a subsequent article will further investigate the samples and results with regard to geological parameters such as particle size distribution and particle shape.
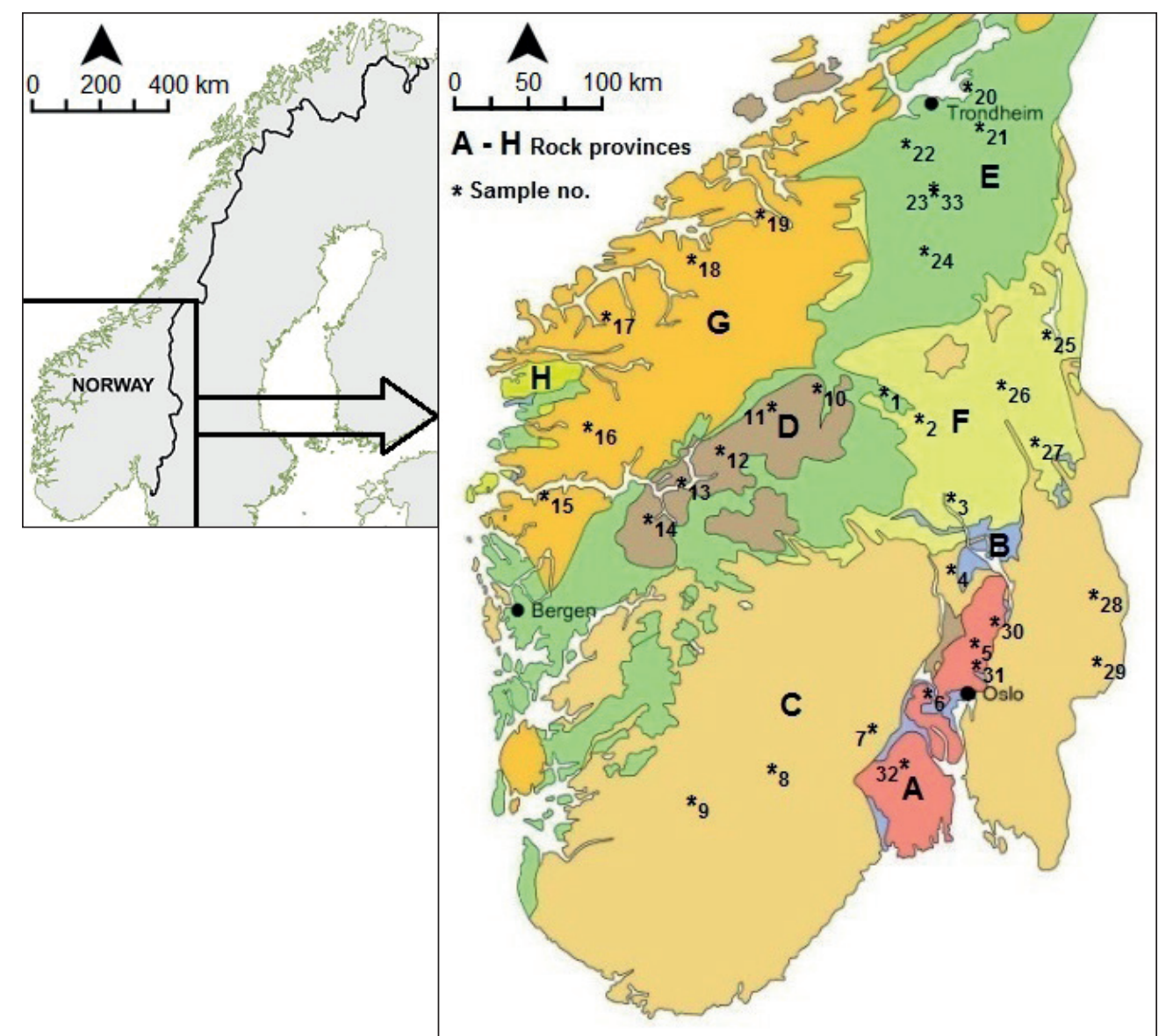

Figure 1. Simplified bedrock geology map of the southern half of Norway illustrating the major rock provinces (named here as A-H) listed in Table 1, and the approximate locations of the 33 till samples listed in Table 2, modified from Norsk Betongforening [NB] (1988, as cited by Haugen \& Lindgård, 2012, p. 3, fig. 22). 
Table 1. A brief description of the major rock provinces (named here as A-H) in Norway, as illustrated on the map in Fig. 1, modified from NB (1988, as cited by Haugen \& Lindgård, 2012) and NGU $(2016 a, b)$.

\begin{tabular}{cc}
\hline Rock province & Description \\
\hline A & Extrusive and plutonic rocks in the Oslo region; mainly syenite, granite, monzonite and rhomb-porphyry \\
B & Sedimentary rocks in the Oslo region; mainly slate, limestone and sandstone \\
C & Caledonian rocks \\
D & Overthrust sheets of Precambrian rocks; mainly metamorphosed plutonic rocks, particularly gabbro \\
E & $\begin{array}{c}\text { Metamorphic and igneous rocks; mainly phyllite, mica schist, metamorphosed sandstone, gneiss and } \\
\text { greenstone }\end{array}$ \\
F & Overthrust sheets of sandstone and schist; mainly sandstone, conglomerate and slate \\
G & Precambrian basement, locally affected by the Caledonian orogeny; mainly gneiss \\
H & Sedimentary rocks; mainly sandstone and conglomerate
\end{tabular}

\section{Methods}

\section{Preliminary work and fieldwork}

Due to the greater variety of bedrock geology in the southern half of Norway (NGU, 2016a), the northern half of Norway was not included in the study. When concentrating on the southern half, the study focused on collecting till samples from a variety of locations. Accordingly, the locations were based on a bedrock geology map from NGU (2016b), as well as a Quaternary geology map (NGU, 2016c) to ensure that the samples were collected from a variety of both geographical and geological provinces. Areas above the marine limit containing till deposits were identified and chosen for further investigation in the field. However, it is often considered difficult to distinguish between different types of till in the field without performing detailed investigations (Dreimanis, 1976; Haldorsen, 1982; Haldorsen \& Krüger, 1990). Thus, for simplicity, the tills sampled in this study were independent of their genesis, i.e., no distinction was made between subglacial till and supraglacial till.

When in the field, the sampling of the tills was done manually with the use of a shovel and bucket. For practical reasons, the sample locations were chosen in natural or man-made slope cuts with minimal vegetation cover, preferably along side slopes to forest roads (Fig. $2 \mathrm{~A}-\mathrm{C})$. The samples were collected from till deposits within roughly $1.5 \mathrm{~m}$ beneath the base of the organic top soil. This was done intentionally so that all samples were approximately from the same depth and therefore relatively similar concerning their possible exposure to processes such as weathering, regardless of the total till cover thickness. Furthermore, about $15 \mathrm{~cm}$ of the uppermost till cover was removed before sampling was done further into the deposit, thus preventing the mixing of other potentially non-local material such as sand from winter road maintenance. Note that the samples collected are disturbed and do not represent the original in situ/field conditions. This was acceptable, as it is considered almost impossible to obtain undisturbed samples in this type of material (Andresen, 1979; Hencher, 2012). Likewise, due to the well-known range in size of solids forming a till, from clay size particles to boulders (Clarke, 1987; Bell, 2002), it was not practically possible to sample or examine the larger fractions such as cobbles and boulders in the laboratory. According to recommendations in BS 1377-7 (1990) one should not include particles larger than $20 \mathrm{~mm}$ in the shear box apparatus. Consequently, and by visual inspection, particles with a diameter clearly larger than $20 \mathrm{~mm}$ were manually sorted out on site and not included in the sampling. Organic material such as roots and insects were also as far as possible removed manually during the sampling. From NS-EN 932-1 (1996), the samples were weighed on site with a spring scale to follow the given standard mass recommendations for a sample with a maximum particle size of $20 \mathrm{~mm}$, i.e., minimum $53 \mathrm{~kg}$ per sample. The collected samples were put in individual plastic barrels and sealed to prevent any mixing of the material during transport. For the same reason, both the shovel and the bucket were cleaned after each sampling.

\section{Laboratory work}

The laboratory work was performed at the Department of Geoscience and Petroleum at the Norwegian University of Science and Technology (NTNU-IGP). As it is known that the reproducibility and repeatability of direct shear test results may vary (Converse, 1953; Bareither et al., 2008a) due to factors such as human imprecision (Thermann et al., 2006), a major focus in this study was that all the samples were prepared and tested as identically as practically possible with the same procedure. This was done to exclude variables and 
Table 2. Overview of the locations of 33 collected till samples from 29 municipalities in 11 counties in the southern half of Norway, also categorised by the rock provinces as shown in Fig. 1.

\begin{tabular}{|c|c|c|c|c|}
\hline Sample no. & Location & Municipality & County & Rock province \\
\hline 1 & Kvam & Nord-Fron & Oppland & $\mathrm{E}$ \\
\hline 2 & Fosse & Sør-Fron & Oppland & $\mathrm{F}$ \\
\hline 3 & Sustad & Lillehammer & Oppland & F \\
\hline 4 & Raufoss & Vestre Toten & Oppland & C \\
\hline 5 & Harestua & Lunner & Oppland & $\mathrm{A} / \mathrm{B}$ \\
\hline 6 & Røyne & Lier & Buskerud & $\mathrm{A} / \mathrm{B}$ \\
\hline 7 & Jondalen & Kongsberg & Buskerud & $\mathrm{C}$ \\
\hline 8 & Brunkeberg & Kviteseid & Telemark & C \\
\hline 9 & Valle & Valle & Aust-Agder & C \\
\hline 10 & Heranostangen & Lom & Oppland & $\mathrm{D}$ \\
\hline 11 & Leirvassbu & Lom & Oppland & $\mathrm{D}$ \\
\hline 12 & Murane & Årdal & Sogn og Fjordane & $\mathrm{D}$ \\
\hline 13 & Kaupanger & Sogndal & Sogn og Fjordane & $\mathrm{D}$ \\
\hline 14 & Jordalen & Voss & Hordaland & $\mathrm{D}$ \\
\hline 15 & Indre Oppedal & Gulen & Sogn og Fjordane & G \\
\hline 16 & Vassenden & Jølster & Sogn og Fjordane & G \\
\hline 17 & Tunga & Volda & Møre og Romsdal & G \\
\hline 18 & Voll & Rauma & Møre og Romsdal & G \\
\hline 19 & Meisalstranda & Nesset & Møre og Romsdal & G \\
\hline 20 & Skatval & Stjørdal & Nord-Trøndelag & E \\
\hline 21 & Tømra & Selbu & Sør-Trøndelag & E \\
\hline 22 & Korsvegen & Melhus & Sør-Trøndelag & $\mathrm{E}$ \\
\hline 23 & Budalen & Midtre Gauldal & Sør-Trøndelag & E \\
\hline 24 & Yset & Tynset & Hedmark & $\mathrm{E}$ \\
\hline 25 & Åkerådalen & Rendalen & Hedmark & $\mathrm{F}$ \\
\hline 26 & Steinbekkbua & Stor-Elvdal & Hedmark & $\mathrm{F}$ \\
\hline 27 & Opphus & Stor-Elvdal & Hedmark & F \\
\hline 28 & Flisa & Åsnes & Hedmark & C \\
\hline 29 & Sørli & Kongsvinger & Hedmark & $\mathrm{C}$ \\
\hline 30 & Sandsnessætra & Nannestad & Akershus & $\mathrm{A} / \mathrm{B}$ \\
\hline 31 & Hakadal & Nittedal & Akershus & $\mathrm{A} / \mathrm{B}$ \\
\hline 32 & Passebekk & Kongsberg & Buskerud & $\mathrm{A} / \mathrm{B}$ \\
\hline 33 & Enodden & Midtre Gauldal & Sør-Trøndelag & $\mathrm{E}$ \\
\hline
\end{tabular}

thereby increase the likelihood of obtaining an equal comparison basis, and, furthermore, so that the results could be linked to the geological parameters of the material. In addition to the main test, six samples were therefore retested for two complete tests to investigate the repeatability of the results.

Initially, the samples were sieved both mechanically and manually for a minimum of five minutes on one single $16 \mathrm{~mm}$ sieve in their original condition, thereby discarding larger particles. As previously described, BS 1377-7 (1990) recommends not including particles larger than $20 \mathrm{~mm}$, so the $16 \mathrm{~mm}$ sieve was chosen due to the likely presence of some larger, elongated particles in the samples. Based on NS-EN 932-2 (1999) and NS-EN 933-1 (2012), a small portion of material of minimum $2.6 \mathrm{~kg}$ from each sample was thereafter randomly selected by splitting with the use of a riffle box, this for the purpose of performing future studies such as particle size distribution. Then, about $40 \mathrm{~kg}$ of each sieved sample $(<16 \mathrm{~mm})$ were put in shallow pans and dried in an oven at $110^{\circ} \mathrm{C} \pm 5^{\circ} \mathrm{C}$ for a minimum of 16 hours, which according to ISO 17892-1 (2014) is normally enough time to achieve a completely dry material. The main reason for drying was to exclude the possibility that the moisture content could be a variable in the testing. 

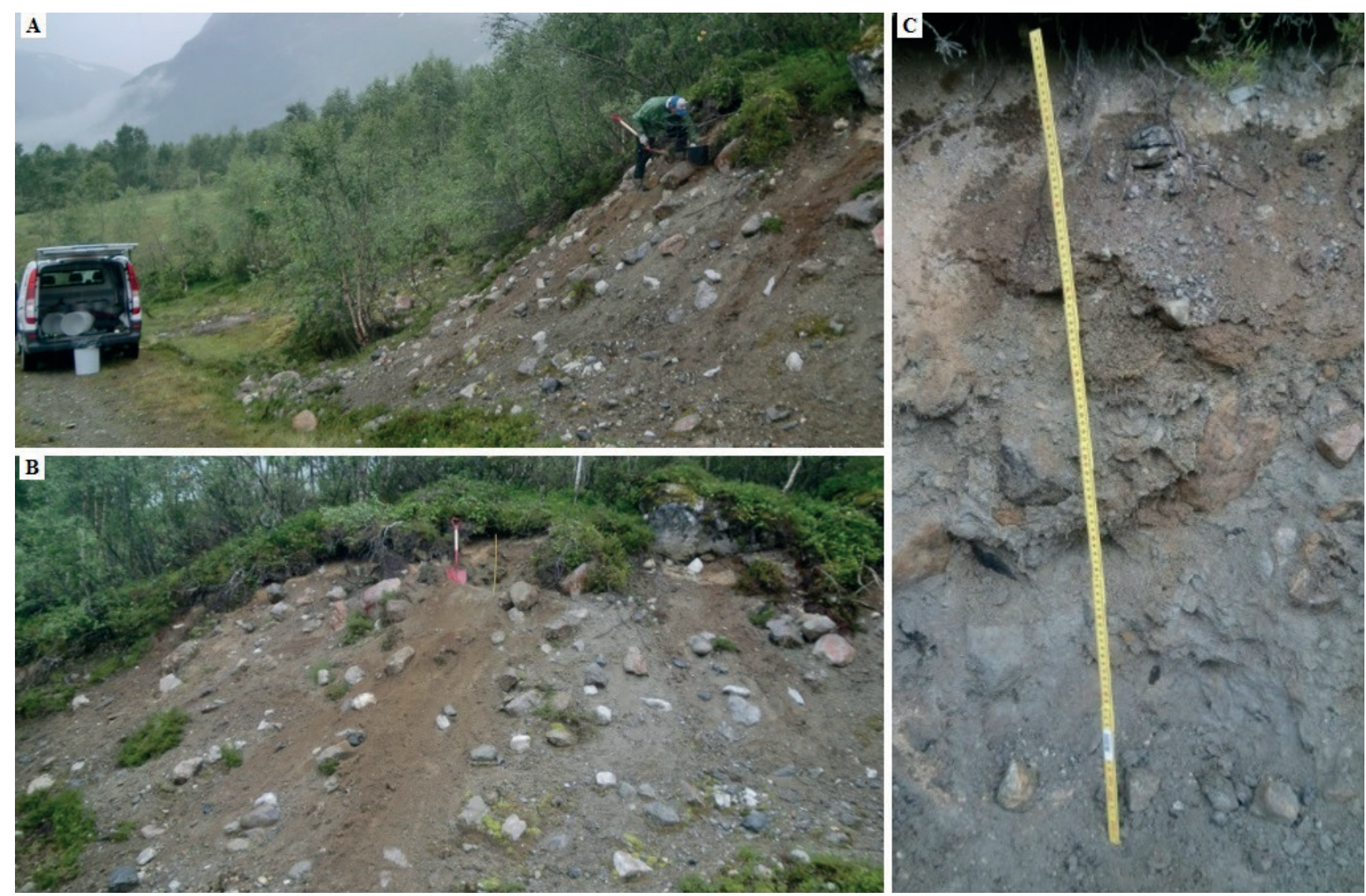

Figure 2. An example of a typical till sampling location, here from sample no. 14, Jordalen in Voss municipality, Hordaland county: (A) A nonvegetated slope cut reachable by car, (B) Overview of the sample site (pit marked by shovel and carpenter's ruler), (C) Excavation of sample pit (the carpenter's ruler is $1 \mathrm{~m}$ ).

After this preparation procedure, the samples were ready to be tested in the SB2010 located at NTNU-IGP, which is a large-scale direct shear box apparatus from Testconsult Ltd. (Fig. 3A, B). The SB2010 is a modern, fully automated machine which incorporates a personal computer for operating the machine, for logging and displaying test data in real time and for reporting test results. During a shear test, the SB2010 automatically registers the shear stress, $\tau$ (rounded to whole numbers of $\mathrm{kPa}$ ), several times per millimetre displacement. The lateral and vertical load capacity range are 0 to $100 \mathrm{kN}$ with a maximum vertical load capacity of $1000 \mathrm{kPa}$ with the use of a precision stepper motor and hydraulics, whereas applied loads are measured directly using calibrated load cells $(0.1 \%$ FS). The maximum inner dimensions of the stainless steel sample box are 305 $\mathrm{mm} \times 305 \mathrm{~mm} \times 200 \mathrm{~mm}$, i.e., length and width (fixed), and height (adjustable sample height), respectively. The SB2010 machine is in full accordance with BS 13777:1990 (Testconsult, 2012).

Before testing the individual samples in the SB2010, the sieved and dried material was firstly weighed in its storage container. The material was then carefully poured into the sample box with the use of a hand scoop (Fig. 4A). The pouring was done into the middle of the box, resulting in a randomised distribution within the box from the middle and outwards. Note that both the surfaces and contact area of the sample box halves were free of lubrication such as grease. A total sample height of approximately $180 \mathrm{~mm}$ was used, and as recommended in BS 1377-7 (1990) the sample was divided into three equally vertical-sized layers. These layers were manually divided and prepared with the use of two self-made wooden tools, ensuring that each layer in every sample was horizontally levelled at best possible equal vertical height, regardless of individual operator accuracy (Fig. 4B). Partly based on BS 1377-7 (1990), each layer was also compacted by doing five drops with a $4 \mathrm{~kg}$ weight (kettlebell) from a fixed height of approximately 20 $\mathrm{cm}$ on top of a steel plate covering the entire layer (Fig. 4C). According to recommendations in the newer ASTM D3080/D3080M (2011) the layer was, after compaction, 'scarified' before establishing a new layer. This scarification was performed with a garden hand fork on the first two layers, i.e., three times in two perpendicular directions over the entire layer area, to avoid distinct layer segregations (Fig. 4D). The last layer was compacted before performing a visual inspection of nine fixed points, i.e., the four corners, sides and the middle, measuring with a ruler the distance in millimetres from top edge of the box down to the top compacted surface of the sample (Fig. 4E, F). This was done to calculate the volume of material contained in 

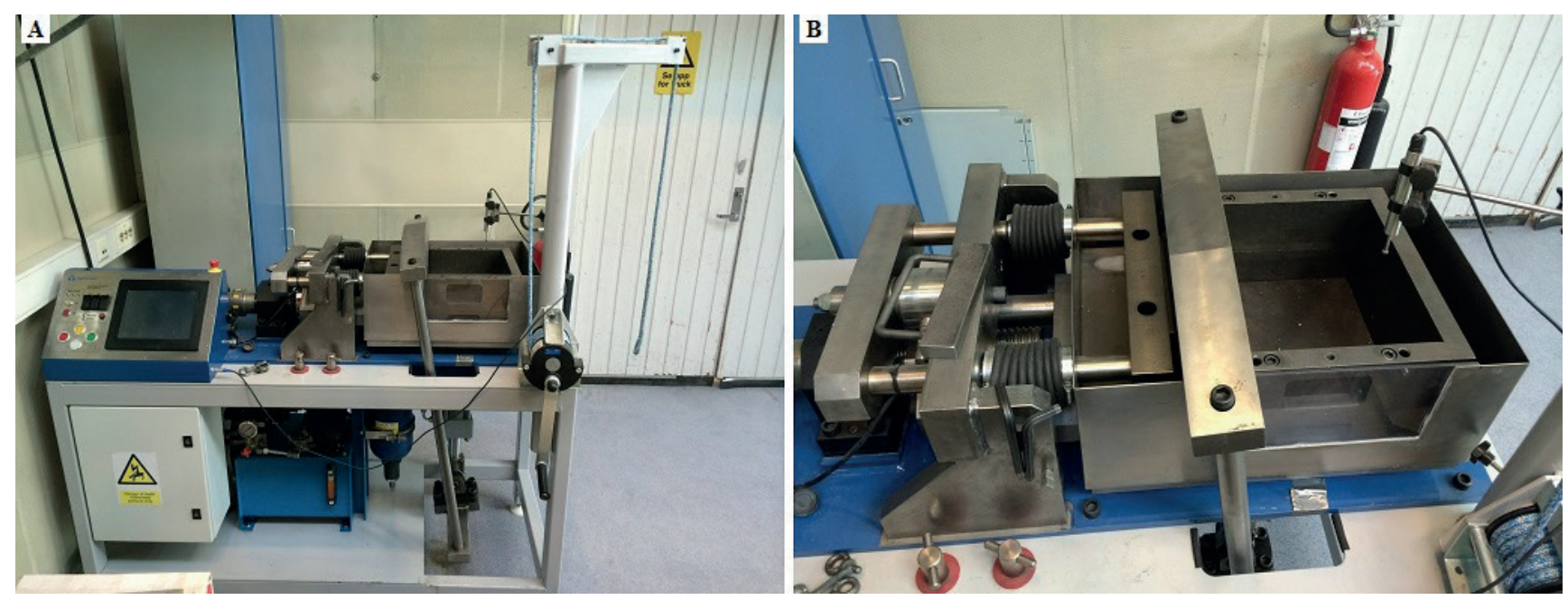

Figure 3. An overview of (A) the SB2010 large-scale direct shear box apparatus located at NTNU-IGP, and (B) with the installed, empty sample box.
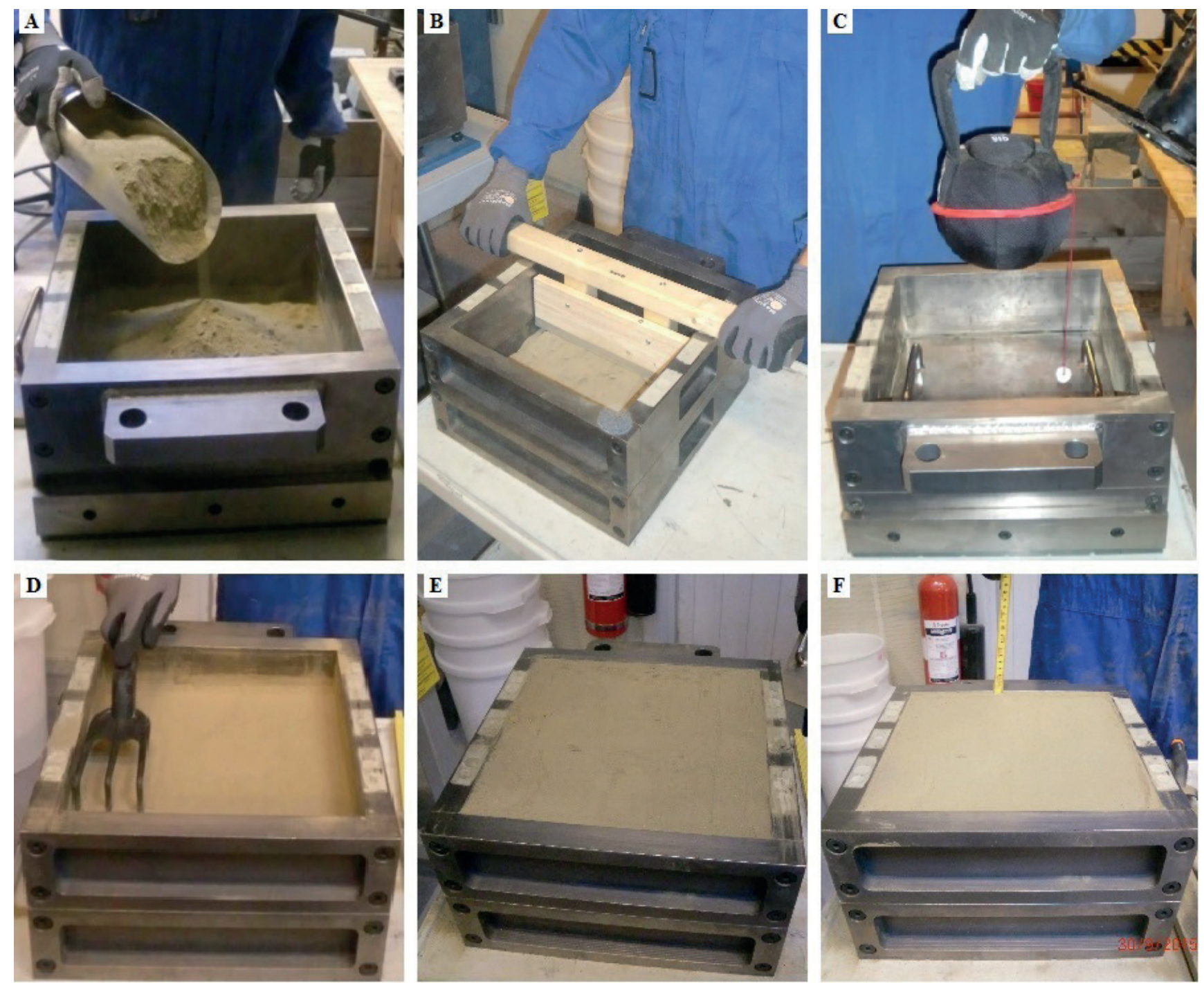

Figure 4. The figures show the shear box testing procedure by preparing the sample for shearing: (A) Pouring of sieved $(<16 \mathrm{~mm})$ and dried till material into the middle of the sample box, (B) Levelling of a total of three equally vertical sized layers (approximately $60 \mathrm{~mm}$ each) with selfmade wooden tools, (C) Initial compaction of each layer by doing five drops from a fixed height of approximately $20 \mathrm{~cm}$ with a $4 \mathrm{~kg} k e t t l e b e l l$ on top of a steel plate, (D) Scarifying the two first compacted layers three times in two perpendicular directions with a garden hand fork to avoid distinct layering, (E) Filled shear box before final compaction, (F) Visual measurement of the sample height from nine fixed points (corners, sides and the middle) after compaction for calculation of sample volume and thereafter the initial dry testing density. 
the sample box. Finally, the steel plate cover was put on top of the compacted material and the sample box was installed in the shear box apparatus. Most of the excess spilled material was with best effort collected and put back into the storage container before it was weighed again, hereby giving the weight of the material contained in the sample box. With approximate information of both mass and volume, the 'initial dry testing density', $\rho_{\mathrm{d}}$, of the sample was calculated once per sample on the first test.

Even though the SB2010 has a programmable shear rate up to $10 \mathrm{~mm} / \mathrm{min}$ (Testconsult, 2012), it seems from other shear test studies that they, in general, have used considerably lower rates, e.g., $0.5 \mathrm{~mm} / \mathrm{min}$ (Fannin et al., 2005), $0.01 \mathrm{~mm} / \mathrm{min}$ (Gan et al., 1988) and $0.005 \mathrm{~mm} / \mathrm{min}$ (Miller \& Hamid, 2007). In addition, ISO 17892-10 (2004) recommends a rate not higher than $0.5 \mathrm{~mm} / \mathrm{min}$. However, the purpose of shearing the sample slowly is, according to ASTM D3080/D3080M (2011), to allow pore-water pressures to dissipate. The samples in this study were, as described, completely dry, thereby avoiding the potential build-up of pore-water pressure. Furthermore, since the water content may also have an influence on the shear strength due to the force of suction (Rahardjo et al., 1995; Fredlund et al., 1996; Lommler, 2012), drying the samples excluded this variable as well. Therefore, the samples were tested with a higher shear rate of $2.0 \mathrm{~mm} / \mathrm{min}$.

Regarding shear distance, ASTM D3080/D3080M (2011) recommends that the sample should be sheared to at least $10 \%$ relative lateral displacement, i.e., minimum $30.5 \mathrm{~mm}$ for the SB2010. Although the SB2010 can shear the sample up to a distance of $50 \mathrm{~mm}$ (Testconsult, 2012), this may lead to spillage of material outside the sample box halves, as well as to a significantly decreased shearing area. Thus, it was decided to shear the samples for a horizontal distance of approximately $40.0 \mathrm{~mm}$, which was also similar to the shear distance in the study done by Bareither et al. (2008b).

As recommended by both BS 1377-7 (1990) and ASTM D3080/D3080M (2011), three shear tests with different normal stress, $\sigma$, were performed on all 33 samples. The three chosen levels of applied normal stress were 100, 200 and $300 \mathrm{kPa}$, as in the study by Skuodis \& Tamošiūnas (2014). These levels of normal stress are relatively high when compared with other studies such as Fannin et al. (2005) and they do not reflect current field conditions. However, the main reason for selecting these levels of normal stress was former laboratory experience at NTNU-IGP showing that the SB2010 was somewhat inaccurate regarding constant loading during tests with a normal stress below $50 \mathrm{kPa}$ (G. Vistnes, pers. comm., 2015). Before each shear test the samples were vertically preloaded at $350 \mathrm{kPa}$ for a period of three minutes, thereby ensuring that all samples had an equal starting condition.

After completion of each shear test, the sample box was emptied, cleaned and refilled as described. On this matter, it must be noted that the samples were reused, which is not recommended in both BS 1377-7 (1990) and ASTM D3080/D3080M (2011), probably due to the potential alteration or deterioration of the material when shearing, e.g., particle crushing. However, as Norwegian rocks are generally recognised as strong (Palmstrøm, 1997; Grimstad et al., 2007), the degree of potential particle crushing was considered to be low. Additionally, the sample box was not exposed to vibration, which would result in an increased particle rearrangement into a denser state. The samples were therefore still in a loose packed state when shear tested. As mentioned, it is known that an increase in the density increases the peak shearing resistance (Simoni \& Houlsby, 2006; Smith, 2014). Hence, shearing the samples in a loose packed state will minimise the risk of alteration or deterioration since there should be little or no dilatancy (Donald, 1956). Thus, the reuse of samples was regarded as having an insignificant influence on the geological parameters and the results. This reuse of the samples was also why lubrication of the sample box was avoided, as it would mix with the dry material thereby reducing the dryness. After completing the three shear tests, both the sample box and the shear box apparatus, as well as the other equipment, were thoroughly cleaned to avoid any mixing of material between different samples.

\section{Supplementary work}

From the locations (Table 2), a simplified bedrock geology map of the southern half of Norway was used as a basis for categorising the sample sites into regional, major rock provinces (Fig. 1; Table 1). For verification, the sample locations by GPS-coordinates were compared to the bedrock geology map from NGU (2016b). In addition to the transport distance of till, another key aspect in this context was the influence of the ice-flow directions which, during the different phases of the Weichselian glaciation, changed due to the shifts of the ice divide (Vorren, 1977). Both regional and local studies by e.g., Bergersen \& Garnes $(1971,1972)$ and Reite $(1994)$ have shown that the Weichselian ice-flow directions have altered quite significantly. Thus, for simplicity, only the major ice-flow directions on a national scale in the late-Weichselian were considered when evaluating the character of the possible rock material assumed to constitute the till samples.

After categorising the sample sites with respect to the major rock provinces $\mathrm{A}-\mathrm{H}$ retrieved from the bedrock geology map, seven out of eight provinces were represented. Province $\mathrm{H}$, which by far was also the smallest province, was not represented. Similarly, province $\mathrm{B}$ was the second smallest in size, but it also overlapped with province A. Due to the relatively small area of province $B$, as well as its overlap with province A, there was a possibility of mixing of the rock types between these two provinces. However, due to the main ice-flow directions in this southeastern part of Norway 


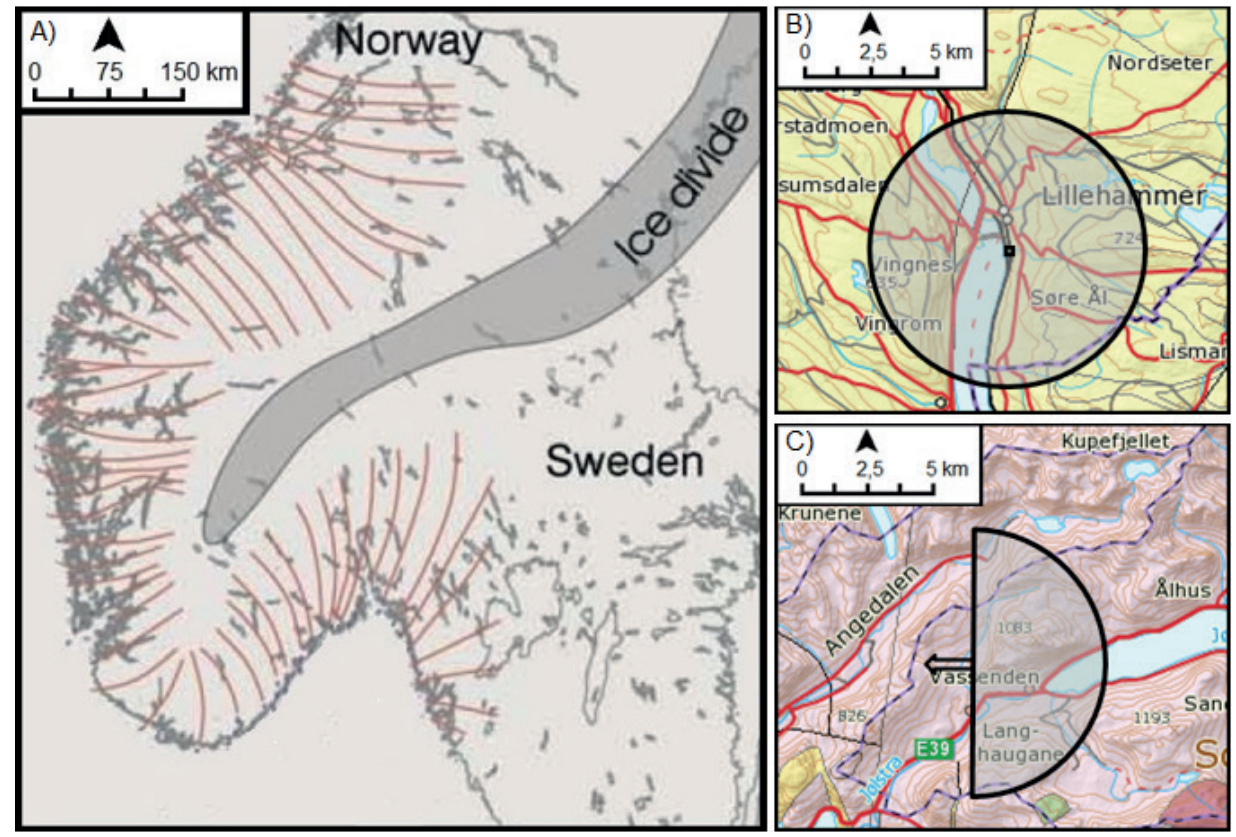

Figure 5. (A) Reconstructed ice-sheet flow regime of the late-Weichselian in the southern half of Norway, where red lines indicate ice-flow directions from the ice divide towards the coastline, modified from Ottesen et al. (2005, p. 1048, fig. 13). (B) Bedrock geology map showing the rock type(s) outside and within a full circle with a radius of five kilometres from sample no. 3, Lillehammer (prov. F), categorised as inside/near the ice divide, (C) Bedrock geology map showing the rock type(s) outside and within a half-circle with a radius of five kilometres from sample no. 16, Jølster (prov. G). This sample is categorised as outside the ice divide with a westward ice-flow direction illustrated by the black arrow. (B) and (C) are modified from NGU (2016b).

(Fig. 5A), it was considered more likely that province A was influenced by province $\mathrm{B}$, rather than the opposite. For simplicity, provinces $\mathrm{A}$ and $\mathrm{B}$ were therefore combined as one province, noted as A/B. Hence, between five to seven samples were collected from each of the remaining six provinces $\mathrm{A} / \mathrm{B}-\mathrm{G}$ (Table 2).

When combining the bedrock geology map (NGU, $2016 \mathrm{~b})$ with the sample sites and the late-Weichselian iceflow directions (Fig. 5A), a full $\left(360^{\circ}\right)$ or half $\left(180^{\circ}\right)$ circle with a radius of about five kilometres was drawn around the center of the sample sites and used as outer limits for sorting out the most likely rock type or types constituting the till samples. A full circle was used for the samples considered to be in or near the area of the ice divide, since the ice-flow directions were unspecified in these areas (Fig. 5B). For samples considered to be outside the ice divide, a half circle was made from the sample site 'downstream' of the major ice-flow direction. Thus, for an ice-flow direction towards the west, rock types east of the sample site were included, while rock types farther west of the sample site were excluded, as this would be 'countercurrent' and therefore considered unlikely (Fig. 5C). After excluding areas on the map where the bedrock is covered, i.e., rivers, lakes and fjords, the up to three most dominant rock types within the remaining radius zone were selected and listed for each sample site. Their assumed influence regarding till content was based on their individual area size within the half or full circle, which were approximately measured in the planar view and calculated. The first rock type listed represents the rock type in the area from which the sample itself was collected, independent of its area size, whereas the remaining rock types are listed with a chronological and decreasing respective percentage share.

The maximum shear stress registered by the SB2010 for the whole displacement length for each shear test was further processed to estimate the angle of friction and cohesion by linear regression analysis, restraining the fit of the data to cohesion $\geq 0 \mathrm{kPa}$. According to BS 1377-7 (1990), the reported angle of friction, $\phi$, was rounded to the nearest $0.5^{\circ}$, while the cohesion, $\mathrm{c}$, was rounded to one decimal place of $\mathrm{kPa}$. The samples and associated results were then summarised in tables for each of the six major rock provinces, including e.g., the average and the standard deviation (SD). In addition, the obtained results were processed for the purpose of graphical visualisation of shear stress vs. horizontal displacement. This simplified plotting was done by choosing the registered shear stress value closest to each whole millimetre from the entire displacement length of each shear test. When processing all the samples in each province, both the highest and lowest registered values (independent of sample number), as well as the average for all samples, for each 'whole millimetre' were plotted. This made it possible to visualise the average curve, and that all the individual curves for each province thus lie somewhere within the minimum and maximum curves. 


\section{Results}

When considering all the 33 samples, the average initial dry testing density, $\rho_{\mathrm{d}}$, was $1.67 \mathrm{~g} / \mathrm{cm}^{3}\left(\mathrm{SD}=0.15 \mathrm{~g} / \mathrm{cm}^{3}\right.$; median $\left.=1.68 \mathrm{~g} / \mathrm{cm}^{3}\right)$. The lowest and highest registered values of $\rho_{\mathrm{d}}$ were $1.39 \mathrm{~g} / \mathrm{cm}^{3}$ (sample no. 5, prov. A/B) and $2.04 \mathrm{~g} / \mathrm{cm}^{3}$ (no. 11, prov. D), respectively, i.e., a difference of $0.65 \mathrm{~g} / \mathrm{cm}^{3}$. For the main shear test with $100 \mathrm{kPa}$ applied normal stress, the average shear stress value, $\tau$, based on the maximum value for each sample, was 84.9 $\mathrm{kPa}(\mathrm{SD}=3.0 \mathrm{kPa}$; median $=85.0 \mathrm{kPa})$, with $78.0 \mathrm{kPa}$ (no. 30, prov. A/B) as the lowest value and $91.0 \mathrm{kPa}$ (no. 12 , prov. D) as the highest value. With the increase of the normal stress to $200 \mathrm{kPa}$, the average shear stress was $163.2 \mathrm{kPa}(\mathrm{SD}=6.5 \mathrm{kPa}$; median $=162.0 \mathrm{kPa})$, with 152.0 $\mathrm{kPa}$ (no. 30, prov. A/B) and $177.0 \mathrm{kPa}$ (no. 16, prov. G) as the lowest and highest values, respectively. For $300 \mathrm{kPa}$ normal stress, the average shear stress was $243.7 \mathrm{kPa}$ (SD $=9.6 \mathrm{kPa}$; median $=246.0 \mathrm{kPa}$ ), with $229.0 \mathrm{kPa}$ (no. 11 , prov. $\mathrm{D}$, and no. 30 , prov. $\mathrm{A} / \mathrm{B}$ ) as the lowest value and $269.0 \mathrm{kPa}$ (no. 12, prov. D) as the highest registered value. Thus, the differences in the shear stress results were up to $13.0 \mathrm{kPa}, 25.0 \mathrm{kPa}$ and $40.0 \mathrm{kPa}$ for 100,200 and 300 $\mathrm{kPa}$ applied normal stress, respectively. Furthermore, the diversities in shear stress resulted in a similar variety of estimated angles of friction, $\phi$, and cohesion, c. The average angle of friction was $38.4^{\circ}\left(\mathrm{SD}=1.3^{\circ}\right.$; median $=$ $38.5^{\circ}$ ), spanning from $36.0^{\circ}$ (no. 26 , prov. F) as the lowest, to $41.5^{\circ}$ (no. 12 , prov. $\mathrm{D}$ ) as the highest registered value, i.e., a difference of $5.5^{\circ}$. Cohesion ranged from $0.0 \mathrm{kPa}$ (nos. 12 and 14, prov. D, and nos. 20 and 21, prov. E) to $11.3 \mathrm{kPa}$ (no. 22, prov. E), with an average of $5.3 \mathrm{kPa}$ (SD $=3.5 \mathrm{kPa}$; median $5.3 \mathrm{kPa}$ ).

Regarding the mapped bedrock geology, the five samples in province A/B ('Extrusive and plutonic rocks/ Sedimentary rocks in the Oslo region'), except for sample no. 6, were dominated by syenites and granites. Apart from sample no. 8 , the other five samples in province $\mathrm{C}$ ('Precambrian basement') were dominated by a variety of gneisses and granites. Province D ('Caledonian rocks, Overthrust sheets of Precambrian rocks') was generally dominated by various mangerite, gabbro, amphibolite and gneiss, whereas sample no. 13 was solely represented by anorthosite. Province E ('Caledonian rocks, Metamorphic and igneous rocks') was the most variable regarding the number of represented rock types in the samples. Overall, mica schist, mica gneiss, amphibolite, greenstone, metasandstone and phyllite were heavily represented in province $\mathrm{E}$. Furthermore, province $\mathrm{F}$ ('Caledonian rocks, Overthrust sheets of sandstone and schist') was relatively homogeneous regarding rock types, as the samples were dominated by sandstone. Lastly, province G ('Caledonian rocks, Precambrian basement, locally affected by the Caledonian orogeny') was also relatively homogeneous regarding rock types, as all of the five samples were dominated by various gneisses and migmatites. The results regarding both bedrock geology and shear test are further elaborated by the individual rock provinces (Figs. 6 \& 7; Tables 3-14) and then summarised in Table 15.

Considering the six samples retested for the purpose of repeatability assessment (Table 16), the results were variably equal to, higher and lower than the ones obtained from the main test. Analysing all six samples for the three test series performed, i.e., a total of nine shear tests per sample, the SD for the shear stress results for 100,200 and $300 \mathrm{kPa}$ normal stress ranged between $1.5-4.0 \mathrm{kPa}, 1.7-4.7 \mathrm{kPa}$, and $2.3-8.1 \mathrm{kPa}$, respectively. For the angle of friction, the SD varied between $0.3^{\circ}$ and $1.3^{\circ}$, while the SD for the cohesion ranged between 2.1 and $7.5 \mathrm{kPa}$.

Table 3. Rock types within $5 \mathrm{~km}$ distance for the five sample sites from rock province A/B, extrusive and plutonic rocks / sedimentary rocks in the Oslo region, from NGU (2016b).

\begin{tabular}{ccc}
\hline Rock province & Sample no. & Rock types \\
\hline 5 & Syenite, quartz syenite $(\sim 86 \%)$; Granite, granodiorite $(\sim 14 \%)$ \\
6 & Phyllite, mica schist $(\sim 28 \%)$; Rhomb-porphyry $(\sim 27 \%)$; Granite, granodiorite $(\sim 16 \%) ;$ Other $(\sim 29 \%)$ \\
A/B & 30 & Syenite, quartz syenite $(\sim 68 \%) ;$ Granite, granodiorite $(\sim 32 \%)$ \\
& 31 & Syenite, quartz syenite $(\sim 83 \%) ;$ Unspecified volcanic rocks $(\sim 8 \%) ;$ Granite, granodiorite $(\sim 7 \%) ;$ Other $(\sim 2 \%)$ \\
& & Granite, granodiorite $(\sim 67 \%) ;$ Monzonite, quartz monzonite $(\sim 24 \%) ;$ Rhomb-porphyry $(\sim 9 \%)$
\end{tabular}


Table 4. The shear test results for the five till samples from rock province $A / B$.

\begin{tabular}{|c|c|c|c|c|c|c|c|}
\hline \multirow{2}{*}{ Rock province } & \multirow{2}{*}{ Sample no. } & \multirow{2}{*}{$\begin{array}{c}\text { Initial dry } \\
\text { testing density, } \\
\rho_{d}\left(\mathrm{~g} / \mathrm{cm}^{3}\right)\end{array}$} & \multicolumn{3}{|c|}{ Max. shear stress, $\tau$, with normal stress, $\sigma(k P a)$} & \multirow{2}{*}{$\begin{array}{c}\text { Angle of } \\
\text { friction, } \phi\left(^{\circ}\right)\end{array}$} & \multirow{2}{*}{$\begin{array}{c}\text { Cohesion, } c \\
\quad(k P a)\end{array}$} \\
\hline & & & $\sigma=100(k P a)$ & $\sigma=200(k P a)$ & $\sigma=300(k P a)$ & & \\
\hline \multirow{5}{*}{$\mathrm{A} / \mathrm{B}$} & 5 & 1.39 & 89.0 & 158.0 & 248.0 & 38.5 & 6.0 \\
\hline & 6 & 1.65 & 85.0 & 159.0 & 235.0 & 37.0 & 9.7 \\
\hline & 30 & 1.76 & 78.0 & 152.0 & 229.0 & 37.0 & 2.0 \\
\hline & 31 & 1.59 & 85.0 & 171.0 & 248.0 & 39.0 & 5.0 \\
\hline & 32 & 1.62 & 87.0 & 167.0 & 246.0 & 38.5 & 7.7 \\
\hline \multicolumn{2}{|c|}{ Average } & 1.60 & 84.8 & 161.4 & 241.2 & 38.0 & 6.1 \\
\hline \multicolumn{2}{|c|}{ Standard deviation } & 0.13 & 4.1 & 7.6 & 8.7 & 0.9 & 2.9 \\
\hline \multicolumn{2}{|c|}{ Median } & 1.62 & 85.0 & 159.0 & 246.0 & 38.5 & 6.0 \\
\hline \multicolumn{2}{|c|}{ Maximum } & 1.76 & 89.0 & 171.0 & 248.0 & 39.0 & 9.7 \\
\hline \multicolumn{2}{|c|}{ Minimum } & 1.39 & 78.0 & 152.0 & 229.0 & 37.0 & 2.0 \\
\hline \multicolumn{2}{|c|}{ Difference } & 0.37 & 11.0 & 19.0 & 19.0 & 2.0 & 7.7 \\
\hline
\end{tabular}

Table 5. Rock types within $5 \mathrm{~km}$ distance for the six sample sites from rock province C, Precambrian basement, from NGU (2016b).

\begin{tabular}{|c|c|c|}
\hline Rock province & Sample no. & Rock types \\
\hline \multirow{6}{*}{$\mathrm{C}$} & 4 & $\begin{array}{l}\text { Augen gneiss, granite, foliated granite }(\sim 18 \%) \text {; Amphibolite, hornblende gneiss, mica gneiss (locally migmatitic) }(\sim 62 \%) \text {; } \\
\text { Sandstone, slate }(\sim 14 \%) \text {; Other }(\sim 6 \%)\end{array}$ \\
\hline & 7 & $\begin{array}{l}\text { Augen gneiss, granite, foliated granite }(\sim 84 \%) \text {; Dioritic to granitic gneiss, migmatite }(\sim 8 \%) \text {; Amphibolite, hornblende } \\
\text { gneiss, mica gneiss (locally migmatitic) }(\sim 4 \%) \text {; Other }(\sim 4 \%)\end{array}$ \\
\hline & 8 & Rhyolite, rhyodacite, dacite, keratophyre ( 34\%); Quartzite ( $40 \%)$; Basalt ( 26\%) \\
\hline & 9 & $\begin{array}{l}\text { Granite, granodiorite ( } \sim 88 \%) \text {; Amphibolite, hornblende gneiss, mica gneiss (locally migmatitic) }(\sim 7 \%) \text {; Augen gneiss, } \\
\text { granite, foliated granite }(\sim 4 \%) \text {; Other }(\sim 1 \%)\end{array}$ \\
\hline & 28 & Gabbro, amphibolite ( $24 \%)$; Dioritic to granitic gneiss, migmatite ( $\sim 43 \%)$; Augen gneiss, granite, foliated granite $(\sim 33 \%)$ \\
\hline & 29 & Augen gneiss, granite, foliated granite ( $\sim 3 \%)$; Dioritic to granitic gneiss, migmatite ( $81 \%)$; Gabbro, amphibolite ( 16\%) \\
\hline
\end{tabular}


Table 6. The shear test results for the six till samples from rock province $C$.

\begin{tabular}{|c|c|c|c|c|c|c|c|}
\hline \multirow{2}{*}{ Rock province } & \multirow{2}{*}{ Sample no. } & \multirow{2}{*}{$\begin{array}{c}\text { Initial dry } \\
\text { testing density, } \\
\rho_{d}\left(\mathrm{~g} / \mathrm{cm}^{3}\right)\end{array}$} & \multicolumn{3}{|c|}{ Max. shear stress, $\tau$, with normal stress, $\sigma(k P a)$} & \multirow{2}{*}{$\begin{array}{c}\text { Angle of } \\
\text { friction, } \phi\left(^{\circ}\right)\end{array}$} & \multirow{2}{*}{$\begin{array}{l}\text { Cohesion, } c \\
\quad(k P a)\end{array}$} \\
\hline & & & $\sigma=100(k P a)$ & $\sigma=200(k P a)$ & $\sigma=300(k P a)$ & & \\
\hline \multirow{6}{*}{$\mathrm{C}$} & 4 & 1.62 & 88.0 & 172.0 & 247.0 & 38.5 & 10.0 \\
\hline & 7 & 1.64 & 87.0 & 172.0 & 256.0 & 40.0 & 2.7 \\
\hline & 8 & 1.76 & 85.0 & 164.0 & 248.0 & 39.0 & 2.7 \\
\hline & 9 & 1.73 & 87.0 & 173.0 & 259.0 & 40.5 & 1.0 \\
\hline & 28 & 1.82 & 82.0 & 158.0 & 231.0 & 36.5 & 8.0 \\
\hline & 29 & 1.81 & 82.0 & 158.0 & 235.0 & 37.5 & 5.3 \\
\hline \multicolumn{2}{|c|}{ Average } & 1.73 & 85.2 & 166.2 & 246.0 & 38.7 & 5.0 \\
\hline \multicolumn{2}{|c|}{ Standard deviation } & 0.08 & 2.6 & 7.1 & 11.1 & 1.5 & 3.5 \\
\hline \multicolumn{2}{|c|}{ Median } & 1.75 & 86.0 & 168.0 & 247.5 & 38.8 & 4.0 \\
\hline \multicolumn{2}{|c|}{ Maximum } & 1.82 & 88.0 & 173.0 & 259.0 & 40.5 & 10.0 \\
\hline \multicolumn{2}{|c|}{ Minimum } & 1.62 & 82.0 & 158.0 & 231.0 & 36.5 & 1.0 \\
\hline \multicolumn{2}{|c|}{ Difference } & 0.20 & 6.0 & 15.0 & 28.0 & 4.0 & 9.0 \\
\hline
\end{tabular}

Table 7. Rock types within $5 \mathrm{~km}$ distance for the five sample sites from rock province D, Caledonian rocks, overthrust sheets of Precambrian rocks, from NGU (2016b).

\begin{tabular}{ccl}
\hline Rock province Sample no. & \multicolumn{1}{c}{ Rock types } \\
\hline 10 & Mangerite to gabbro, gneiss and amphibolite $(\sim 96 \%) ;$ Olivine rock, pyroxenite $(\sim 3 \%) ;$ Phyllite, mica schist $(\sim 1 \%)$ \\
11 & Mangerite to gabbro, gneiss and amphibolite $(\sim 100 \%)$ \\
12 & Mangerite to gabbro, gneiss and amphibolite $(\sim 74 \%) ;$ Gabbro, amphibolite $(\sim 16 \%) ;$ Dioritic to granitic gneiss $(\sim 10 \%)$ \\
13 & Anorthosite $(\sim 100 \%)$ \\
& 14 & Mangerite-syenite $(\sim 84 \%) ;$ Anorthosite $(\sim 12 \%) ;$ Dioritic to migmatitic gneiss $(\sim 3 \%) ;$ Other $(\sim 1 \%)$ \\
\hline
\end{tabular}

Table 8. The shear test results for the five till samples from rock province D.

\begin{tabular}{|c|c|c|c|c|c|c|c|}
\hline \multirow{2}{*}{ Rock province } & \multirow{2}{*}{ Sample no. } & \multirow{2}{*}{$\begin{array}{c}\text { Initial dry } \\
\text { testing density, } \\
\rho_{d}\left(\mathrm{~g} / \mathrm{cm}^{3}\right)\end{array}$} & \multicolumn{3}{|c|}{ Max. shear stress, $\tau$, with normal stress, $\sigma(k P a)$} & \multirow{2}{*}{$\begin{array}{c}\text { Angle of } \\
\text { friction, } \phi\left(^{\circ}\right)\end{array}$} & \multirow{2}{*}{$\begin{array}{l}\text { Cohesion, } c \\
\quad(k P a)\end{array}$} \\
\hline & & & $\sigma=100(k P a)$ & $\sigma=200(k P a)$ & $\sigma=300(k P a)$ & & \\
\hline \multirow{5}{*}{$\mathrm{D}$} & 10 & 1.89 & 85.0 & 160.0 & 242.0 & 38.0 & 5.3 \\
\hline & 11 & 2.04 & 81.0 & 159.0 & 229.0 & 36.5 & 8.3 \\
\hline & 12 & 1.79 & 91.0 & 170.0 & 269.0 & 41.5 & 0.0 \\
\hline & 13 & 1.68 & 84.0 & 165.0 & 246.0 & 39.0 & 3.0 \\
\hline & 14 & 1.71 & 84.0 & 162.0 & 251.0 & 39.5 & 0.0 \\
\hline \multicolumn{2}{|c|}{ Average } & 1.82 & 85.0 & 163.2 & 247.4 & 38.9 & 3.3 \\
\hline \multicolumn{2}{|c|}{ Standard deviation } & 0.15 & 3.7 & 4.4 & 14.6 & 1.9 & 3.6 \\
\hline \multicolumn{2}{|c|}{ Median } & 1.79 & 84.0 & 162.0 & 246.0 & 39.0 & 3.0 \\
\hline \multicolumn{2}{|c|}{ Maximum } & 2.04 & 91.0 & 170.0 & 269.0 & 41.5 & 8.3 \\
\hline \multicolumn{2}{|c|}{ Minimum } & 1.68 & 81.0 & 159.0 & 229.0 & 36.5 & 0.0 \\
\hline \multicolumn{2}{|c|}{ Difference } & 0.36 & 10.0 & 11.0 & 40.0 & 5.0 & 8.3 \\
\hline
\end{tabular}


Table 9. Rock types within $5 \mathrm{~km}$ distance for the seven sample sites from rock province E, Caledonian rocks, metamorphic and igneous rocks, from NGU (2016b).

\begin{tabular}{|c|c|c|}
\hline Rock province & Sample no. & Rock types \\
\hline \multirow{7}{*}{$\mathrm{E}$} & 1 & $\begin{array}{l}\text { Phyllite, mica schist }(\sim 47 \%) \text {; Metasandstone, mica schist }(\sim 31 \%) \text {; Amphibolite, hornblende gneiss, mica gneiss (locally } \\
\text { migmatitic) }(\sim 18 \%) \text {; Other }(\sim 4 \%)\end{array}$ \\
\hline & 20 & Greenstone, amphibolite ( $54 \%)$; Slate, sandstone, limestone ( 38\%); Conglomerate, sedimentary breccia $(\sim 7 \%)$; Other $(\sim 1 \%)$ \\
\hline & 21 & Phyllite, mica schist ( 77\%); Quartzite ( 17\%); Greenstone, amphibolite ( 6\%) \\
\hline & 22 & $\begin{array}{l}\text { Greenstone, amphibolite ( 29\%); Slate, sandstone, limestone ( 37\%); Unspecified volcanic rocks }(\sim 21 \%) \text {; } \\
\text { Other }(\sim 13 \%)\end{array}$ \\
\hline & 23 & Greenstone, amphibolite ( $\sim 5 \%)$; Mica gneiss, mica schist, metasandstone, amphibolite $(\sim 65 \%)$; Quartzite $(\sim 30 \%)$ \\
\hline & 24 & Mica gneiss, mica schist, meta-sandstone, amphibolite ( 97\%); Greenstone, amphibolite ( 3\%) \\
\hline & 33 & Mica gneiss, mica schist, metasandstone, amphibolite ( $92 \%)$; Quartzite $(\sim 6 \%)$; Greenstone, amphibolite $(\sim 2 \%)$ \\
\hline
\end{tabular}

Table 10. The shear test results for the five till samples from rock province $E$.

\begin{tabular}{|c|c|c|c|c|c|c|c|}
\hline \multirow{2}{*}{ Rock province } & \multirow{2}{*}{ Sample no. } & \multirow{2}{*}{$\begin{array}{c}\text { Initial dry } \\
\text { testing density, } \\
\rho_{d}\left(\mathrm{~g} / \mathrm{cm}^{3}\right)\end{array}$} & \multicolumn{3}{|c|}{ Max. shear stress, $\tau$, with normal stress, $\sigma(k P a)$} & \multirow{2}{*}{$\begin{array}{c}\text { Angle of } \\
\text { friction, } \phi\left(^{\circ}\right)\end{array}$} & \multirow{2}{*}{$\begin{array}{c}\text { Cohesion, } c \\
\quad(k P a)\end{array}$} \\
\hline & & & $\sigma=100(k P a)$ & $\sigma=200(k P a)$ & $\sigma=300(k P a)$ & & \\
\hline \multirow{7}{*}{$\mathrm{E}$} & 1 & 1.70 & 88.0 & 171.0 & 247.0 & 38.5 & 9.7 \\
\hline & 20 & 1.67 & 82.0 & 163.0 & 250.0 & 39.5 & 0.0 \\
\hline & 21 & 1.41 & 82.0 & 163.0 & 246.0 & 39.5 & 0.0 \\
\hline & 22 & 1.54 & 89.0 & 164.0 & 243.0 & 37.5 & 11.3 \\
\hline & 23 & 1.55 & 83.0 & 157.0 & 232.0 & 36.5 & 8.3 \\
\hline & 24 & 1.44 & 87.0 & 158.0 & 240.0 & 37.5 & 8.7 \\
\hline & 33 & 1.53 & 80.0 & 155.0 & 233.0 & 37.5 & 3.0 \\
\hline \multicolumn{2}{|c|}{ Average } & 1.55 & 84.4 & 161.6 & 241.6 & 38.1 & 5.9 \\
\hline \multicolumn{2}{|c|}{ Standard deviation } & 0.11 & 3.5 & 5.4 & 6.9 & 1.1 & 4.7 \\
\hline \multicolumn{2}{|c|}{ Median } & 1.54 & 83.0 & 163.0 & 243.0 & 37.5 & 8.3 \\
\hline \multicolumn{2}{|c|}{ Maximum } & 1.70 & 89.0 & 171.0 & 250.0 & 39.5 & 11.3 \\
\hline \multicolumn{2}{|c|}{ Minimum } & 1.41 & 80.0 & 155.0 & 232.0 & 36.5 & 0.0 \\
\hline \multicolumn{2}{|c|}{ Difference } & 0.29 & 9.0 & 16.0 & 18.0 & 3.0 & 11.3 \\
\hline
\end{tabular}

Table 11. Rock types within $5 \mathrm{~km}$ distance for the five sample sites from rock province F, Caledonian rocks, overthrust sheets of sandstone and schist, from NGU (2016b).

\begin{tabular}{ccl}
\hline Rock province Sample no. & \multicolumn{1}{c}{ Rock types } \\
\hline & 2 & Sandstone $(\sim 65 \%)$; Metasandstone, mica schist $(\sim 22 \%)$; Quartzite $(\sim 6 \%)$; Other $(\sim 7 \%)$ \\
3 & Sandstone $(\sim 100 \%)$ \\
25 & Sandstone $(\sim 100 \%)$ \\
& 26 & Sandstone $(\sim 88 \%)$; Quartzite $(\sim 10 \%)$; Conglomerate, sedimentary breccia $(\sim 1 \%)$; Other $(\sim 1 \%)$ \\
& & Sandstone $(\sim 93 \%)$; Conglomerate, sedimentary breccia $(\sim 6 \%)$; Limestone, dolomite $(\sim 1 \%)$ \\
\hline
\end{tabular}


Table 12. The shear test results for the five till samples from rock province F.

\begin{tabular}{|c|c|c|c|c|c|c|c|}
\hline \multirow{2}{*}{ Rock province } & \multirow{2}{*}{ Sample no. } & \multirow{2}{*}{$\begin{array}{c}\text { Initial dry } \\
\text { testing density, } \\
\rho_{d}\left(\mathrm{~g} / \mathrm{cm}^{3}\right)\end{array}$} & \multicolumn{3}{|c|}{ Max. shear stress, $\tau$, with normal stress, $\sigma(k P a)$} & \multirow{2}{*}{$\begin{array}{c}\text { Angle of } \\
\text { friction, } \phi\left(^{\circ}\right)\end{array}$} & \multirow{2}{*}{$\begin{array}{l}\text { Cohesion, } \\
\quad(k P a)\end{array}$} \\
\hline & & & $\sigma=100(k P a)$ & $\sigma=200(k P a)$ & $\sigma=300(k P a)$ & & \\
\hline \multirow{5}{*}{$\mathrm{F}$} & 2 & 1.59 & 89.0 & 167.0 & 249.0 & 38.5 & 8.3 \\
\hline & 3 & 1.43 & 81.0 & 156.0 & 232.0 & 37.0 & 5.3 \\
\hline & 25 & 1.73 & 85.0 & 159.0 & 237.0 & 37.0 & 8.3 \\
\hline & 26 & 1.90 & 84.0 & 157.0 & 230.0 & 36.0 & 11.0 \\
\hline & 27 & 1.46 & 82.0 & 158.0 & 240.0 & 38.5 & 2.0 \\
\hline \multicolumn{2}{|c|}{ Average } & 1.62 & 84.2 & 159.4 & 237.6 & 37.4 & 7.0 \\
\hline \multicolumn{2}{|c|}{ Standard deviation } & 0.20 & 3.1 & 4.4 & 7.5 & 1.1 & 3.4 \\
\hline \multicolumn{2}{|c|}{ Median } & 1.59 & 84.0 & 158.0 & 237.0 & 37.0 & 8.3 \\
\hline \multicolumn{2}{|c|}{ Maximum } & 1.90 & 89.0 & 167.0 & 249.0 & 38.5 & 11.0 \\
\hline \multicolumn{2}{|c|}{ Minimum } & 1.43 & 81.0 & 156.0 & 230.0 & 36.0 & 2.0 \\
\hline \multicolumn{2}{|c|}{ Difference } & 0.47 & 8.0 & 11.0 & 19.0 & 2.5 & 9.0 \\
\hline
\end{tabular}

Table 13. Rock types within $5 \mathrm{~km}$ distance for the five sample sites from rock province G, Caledonian rocks, Precambrian basement, locally affected by the Caledonian orogeny, from NGU (2016b).

\begin{tabular}{ccl}
\hline Rock province Sample no. & \multicolumn{1}{c}{ Rock types } \\
\hline & 15 & Dioritic to granitic gneiss, migmatite $(\sim 97 \%) ;$ Augen gneiss, granite, foliated gneiss $(\sim 3 \%)$ \\
& 16 & Dioritic to granitic gneiss, migmatite $(\sim 100 \%)$ \\
G & 17 & Dioritic to granitic gneiss, migmatite $(\sim 99 \%) ;$ Olivine rock, pyroxenite $(\sim 1 \%)$ \\
& 18 & Dioritic to granitic gneiss, migmatite $(\sim 100 \%)$ \\
& 19 & Dioritic to granitic gneiss, migmatite $(\sim 92 \%) ;$ Amphibolite and mica schist $(\sim 8 \%)$
\end{tabular}

Table 14. The shear test results for the five till samples from rock province $G$.

\begin{tabular}{|c|c|c|c|c|c|c|c|}
\hline \multirow{2}{*}{ Rock province } & \multirow{2}{*}{ Sample no. } & \multirow{2}{*}{$\begin{array}{c}\text { Initial dry } \\
\text { testing density, } \\
\rho_{d}\left(\mathrm{~g} / \mathrm{cm}^{3}\right)\end{array}$} & \multicolumn{3}{|c|}{ Max. shear stress, $\tau$, with normal stress, $\sigma(k P a)$} & \multirow{2}{*}{$\begin{array}{c}\text { Angle of } \\
\text { friction, } \phi\left(^{\circ}\right)\end{array}$} & \multirow{2}{*}{$\begin{array}{c}\text { Cohesion, } c \\
\text { (kPa) }\end{array}$} \\
\hline & & & $\sigma=100(k P a)$ & $\sigma=200(k P a)$ & $\sigma=300(k P a)$ & & \\
\hline \multirow{5}{*}{ G } & 15 & 1.74 & 89.0 & 174.0 & 255.0 & 39.5 & 6.7 \\
\hline & 16 & 1.62 & 86.0 & 177.0 & 253.0 & 40.0 & 5.0 \\
\hline & 17 & 1.69 & 86.0 & 170.0 & 253.0 & 40.0 & 2.7 \\
\hline & 18 & 1.71 & 84.0 & 161.0 & 239.0 & 38.0 & 6.3 \\
\hline & 19 & 1.75 & 84.0 & 157.0 & 244.0 & 38.5 & 1.7 \\
\hline \multicolumn{2}{|c|}{ Average } & 1.70 & 85.8 & 167.8 & 248.8 & 39.2 & 4.5 \\
\hline \multicolumn{2}{|c|}{ Standard deviation } & 0.05 & 2.0 & 8.5 & 6.9 & 0.9 & 2.2 \\
\hline \multicolumn{2}{|c|}{ Median } & 1.71 & 86.0 & 170.0 & 253.0 & 39.5 & 5.0 \\
\hline \multicolumn{2}{|c|}{ Maximum } & 1.75 & 89.0 & 177.0 & 255.0 & 40.0 & 6.7 \\
\hline \multicolumn{2}{|c|}{ Minimum } & 1.62 & 84.0 & 157.0 & 239.0 & 38.0 & 1.7 \\
\hline \multicolumn{2}{|c|}{ Difference } & 0.13 & 5.0 & 20.0 & 16.0 & 2.0 & 5.0 \\
\hline
\end{tabular}




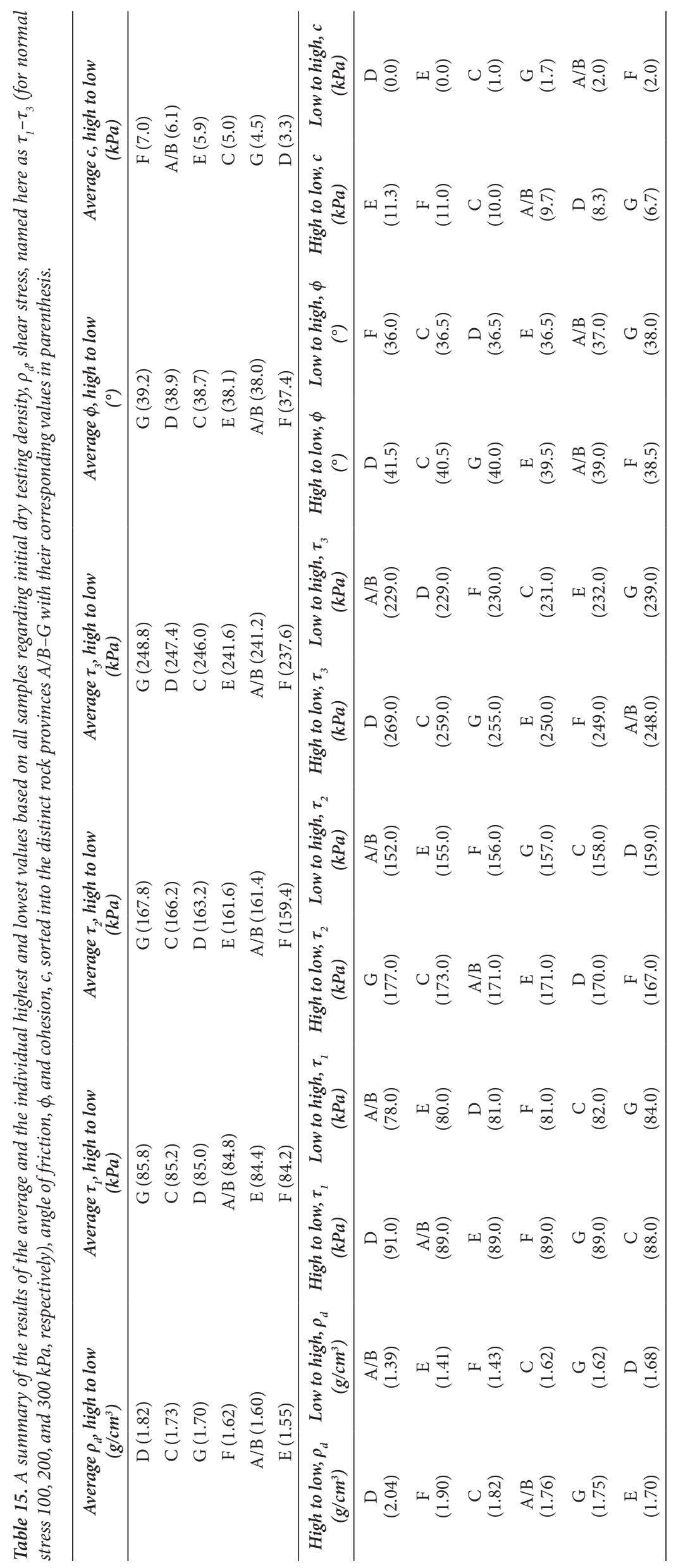

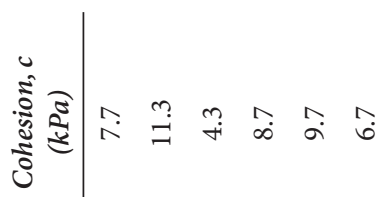

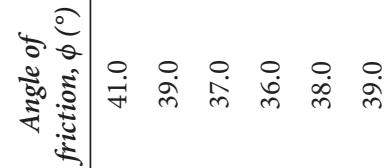

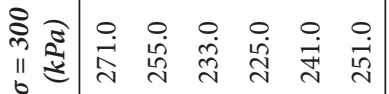
is

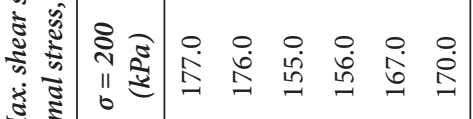
$\ddot{m} \vdots$ 离离

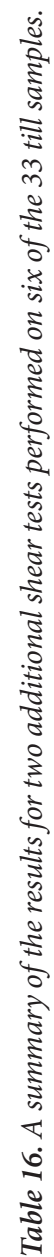

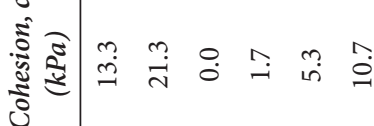

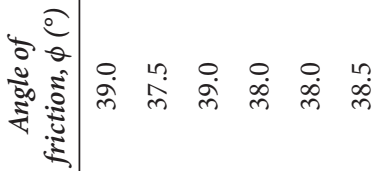

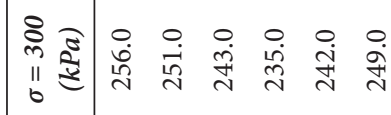

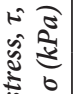

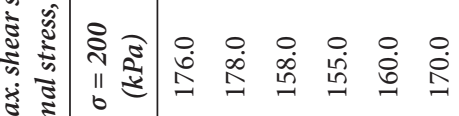
这

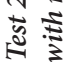



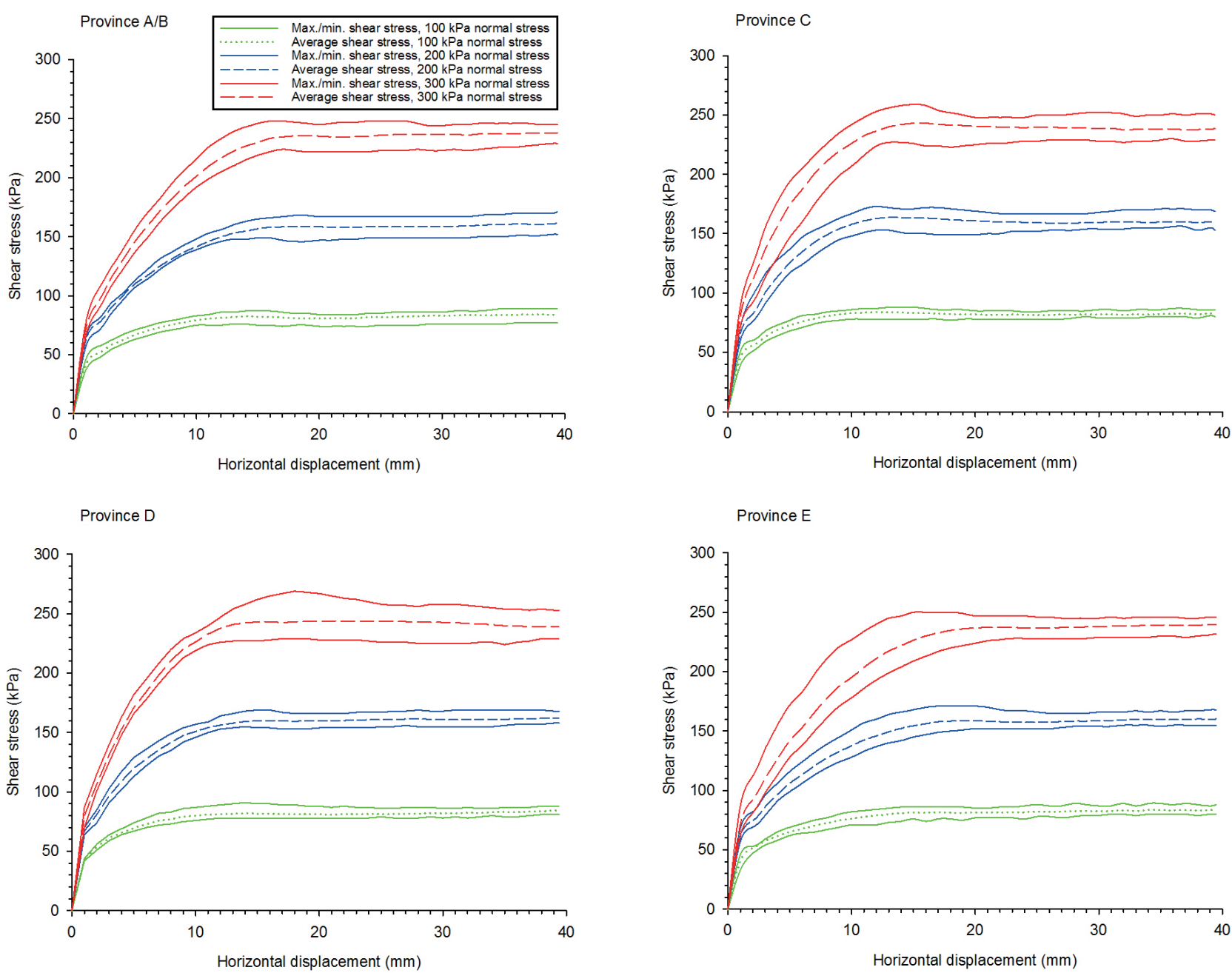

Province F

Province G
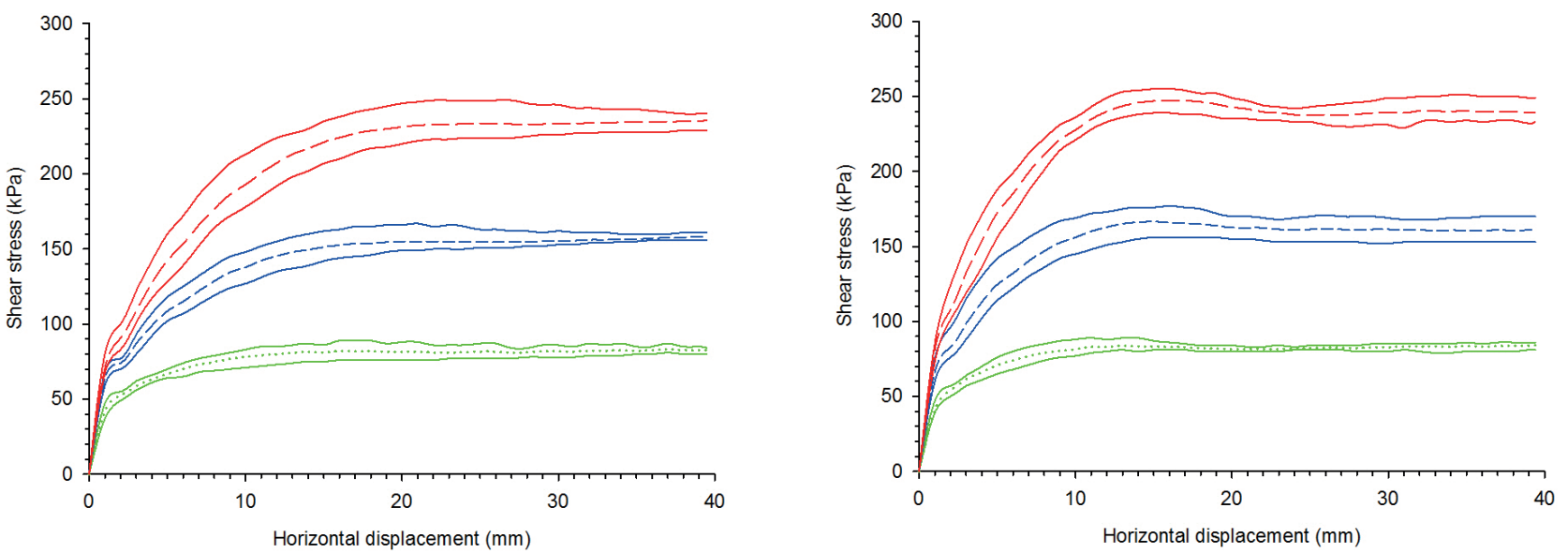

Figure 6. Shear test results for the till samples from each of the six rock provinces, $A / B-G$. 
A) Average shear stress for provinces A/B - G, $100 \mathrm{kPa}$ normal stress

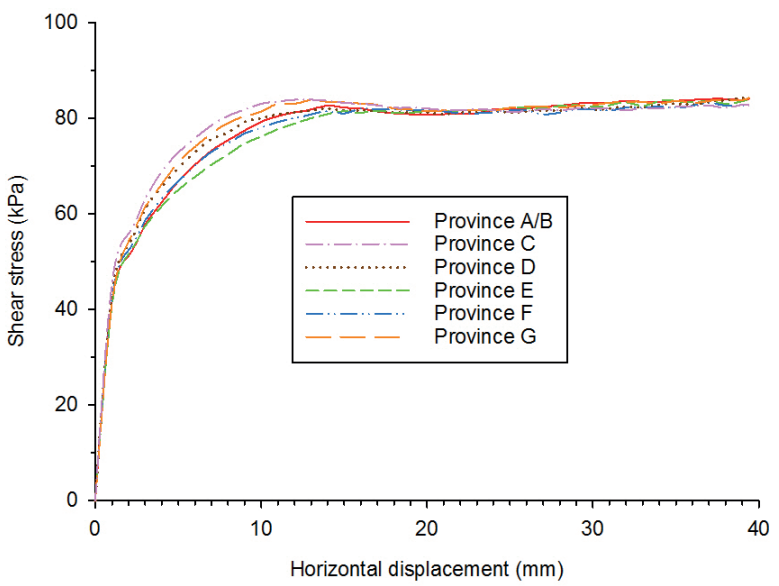

C) Average shear stress for provinces A/B - G, $300 \mathrm{kPa}$ normal stress

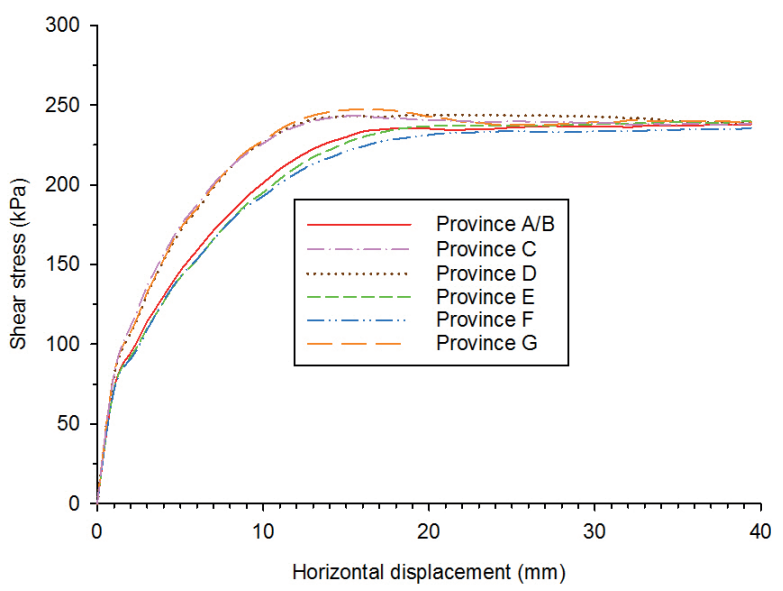

\section{Discussion}

During the fieldwork there were some challenges regarding field interpretation for selecting the ideal sample sites. The tills were, for practical reasons, therefore chosen independently of genesis. However, genesis is known to influence the geotechnical properties of tills through its control on important characteristics such as stress history and particle size distribution. Also, post-depositional processes, such as wetting and drying, freezing and thawing, and downward percolation of fines, may further change the characteristics of the till (Boulton \& Paul, 1976). As such variables are not accounted for in the sampling, they are sources of uncertainty for the representativeness of the samples regarding the area from which they are collected and, consequently, for the interpretation of the shear test results.

Furthermore, to distinguish a till deposit from an old, revegetated debris slide/flow deposit of till material was also rather challenging as the outcrops were commonly limited. According to Cammeraat \& Rappol (1987), there is a possibility that till-like resedimentation products (debris flows) may be incorporated in the
B) Average shear stress for provinces A/B - G, $200 \mathrm{kPa}$ normal stress

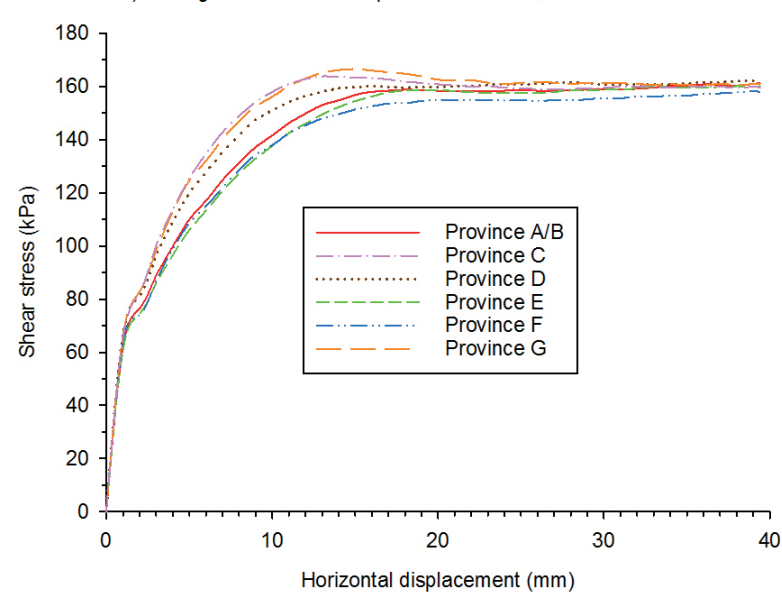

Figure 7. Average shear stress vs. horizontal displacement for all samples categorised in each of the six rock provinces $A / B-G$ for $(A)$ $100 \mathrm{kPa}$, (B) $200 \mathrm{kPa}$ and (C) $300 \mathrm{kPa}$ normal stress.

sampling, as these can be difficult to differentiate from true tills in such cases where the exposure in the field is poor. Additionally, the degree of detailed mapping available from the Quaternary geology map (NGU, 2016c), especially in the transition zone from one deposit type to another, is quite poor in some areas. Although focusing on locations marked on the map as till, one cannot exclude the possibility that some of the samples are, in fact, from e.g., debris slide/flow deposits of till material. Yet, this latter potential source of uncertainty was regarded as having no significant influence, as the sampling itself disturbed the material.

The samples were not tested in their in situ state, as it is regarded as nearly impossible to collect perfectly undisturbed samples of till (e.g., Andresen, 1979). The disturbed samples were also prepared in the laboratory with sieving, splitting, drying and compacting before shear testing. According to Vanapalli et al. (1996), the laboratory preparation of samples must closely represent the physical conditions and the stress state conditions likely to occur in the field if a proper assessment of the shear strength parameters is to be achieved. For example, it is considered as practically impossible to obtain a soil 
with zero saturation (Budhu, 2015), thus making the dried samples in this study not representable for normal Norwegian field conditions. As water is a main trigger for Norwegian debris slides and flows (e.g., Kronholm et al., 2007; Bargel et al., 2011), shear testing the samples in saturated conditions instead of in a dry condition would clearly be more appropriate for practical applications regarding slope stability assessment. In practice, however, including water in the testing would introduce a variable hard to control. This is due to significant differences of the geological parameters amongst the till samples, such as the particle size distribution, which could lead to, e.g., inhomogeneous saturation in the material and removal of fines. This, in turn, would potentially introduce a significant uncertainty to the results. Moreover, the relatively high levels of applied normal stress do not reflect current field conditions either. Consequently, these results are not likely to replicate the factual in situ/field conditions at the sample sites regarding till shear strength. Nevertheless, and as initially stated, the samples in this study were not tested with the purpose of replicating their field conditions, but with the same procedure for achieving a best possible, equal comparison basis. Hence, the aim of the study was to show if shear strength differences in relation to bedrock geology and the respective rock provinces do exist, regardless of individual field variables such as stress state, density and water content. Excluding these, although highly important, variables was considered necessary to be able to establish equal conditions of testing with a minimum of laboratory variables, and, accordingly, so that the results could be linked to the geological parameters (particle shape, size, etc.) of the samples.

Independently of uncertainties in the sampling and testing procedure, one should also evaluate the apparatus that was used. Regarding the use of a shear box apparatus, Das (2010) pointed out that the direct shear test method has some inherent shortcomings. For example, the reliability of shear box results may, in general, be questioned because the soil is forced to fail along the contact plane of the two halves of the box, rather than along a potentially weaker plane in the sample. However, the disturbed, heterogeneous material tested in this study should be relatively homogeneous when prepared in the sample box, thereby having no significantly weaker planes than the plane of split. Although the shear strength can be found by using other laboratory tests, such as the triaxial test, the direct shear test is considered to be the simplest and most economical for a dry sandy soil (Das, 2010), and, according to Lommler (2012), the commercial laboratory test of choice for granular soils.

Furthermore, according to e.g., Hooke (2005), detailed measurements often show that the variation of yield strength with effective normal pressure is not linear at low effective normal pressures, hereby giving rise to the terms 'true cohesion' and 'apparent cohesion'. While till may have true cohesion (Hooke, 2005; Hungr et al.,
2005), Cuffey \& Paterson (2010) have pointed out that in shear at critical state the till has no true cohesion. Also, since these samples were prepared from disturbed material, there could certainly be no true cohesion (Hencher, 2012). Thus, the values of cohesion reported here are not true cohesion, but obtained values from the linear regression analysis.

As the reproducibility and repeatability of the results from shear tests may vary (e.g., Bareither et al., 2008a), six of the samples were retested to observe the possible change of results (Table 16). Bareither et al. (2008a) investigated the repeatability and reproducibility of direct shear tests on granular backfill material (sand). In that context, 'repeatability' meant testing identical items in the same laboratory by the same operator using both the same method and equipment (intra-laboratory), while 'reproducibility' meant testing the identical items with the same method, but in 10 other laboratories by different operators and equipment (inter-laboratory). In summary, the reproducibility varied significantly more than the repeatability. Regarding repeatability, the intralaboratory tests on the angle of friction led to a SD of $0.1^{\circ}$. On the other hand, the inter-laboratory tests reported an average reproducibility of $8.8^{\circ}$, with a range of variability up to $18.8^{\circ}$. Compared to the present study, where the $\mathrm{SD}$ of the angle of friction ranged from $0.3^{\circ}$ to $1.3^{\circ}$, the results were considerably better than the reproducibility results reported by Bareither et al. (2008a), although the repeatability was not as good. However, the reason for this diversity of results may be due to factors such as the difference of material used (relatively homogeneous sand vs. heterogeneous till material) as well as the number of tests performed (five vs. three). For these reasons, the results presented in Table 16 were considered satisfactory regarding the assessment of repeatability.

Moreover, on the issue of repeatability, studies by e.g., Feda (2002) and Hattamleh et al. (2010) have reported changes in shear strength due to particle crushing, which initially was also of some concern in this study, especially due to the necessary reuse of samples. Yet, when retesting six of the samples, the results were either equal to, higher and lower than the ones obtained from the main test. This strengthened the initial assumption that the samples would not be noticeably damaged or altered by reuse. Although there were some clear differences in some of the additional tests, it is difficult to isolate the exact reason(s), as these may be due to uncertainties in the shear box apparatus, geological parameters, procedure, operator, or a combination of these. Since the samples consist of gravel, sand and fines, emptying and refilling the sample box gives significantly more combinations of particle arrangements and interactions and, as a result, the repeatability should therefore vary more than retesting, e.g., a homogeneous sand.

Internationally, from shear tests on multiple tills from eastern England, Bell (2002) presented angles of friction 
mainly ranging from approximately $20^{\circ}$ to $30^{\circ}$, although the fraction of fines composed up to $60-80 \%$ of these tills. Iverson et al. (1994) reported an angle of friction of $31^{\circ}$ in a till from Sweden, while a study by Rathbun et al. (2008) on two tills from Alaska and Ohio, USA, resulted in $31.4^{\circ}$ and $29.4^{\circ}$, respectively. Others have reported that the angle of friction for till ranges between $35^{\circ}$ and $45^{\circ}$ (Koloski et al., 1989). Clearly, the angles of friction for tills may vary significantly. Considering the previously mentioned shear test studies of Norwegian tills, Lund (2013), Langåker (2014) and Langeland (2016) investigated one locality each, i.e., Nesbyen in Nes municipality, Buskerud county, Seim in Granvin municipality, Hordaland county, and Soknedal in Midtre Gauldal municipality, Sør-Trøndelag county, respectively. The angles of friction in the study by Langaker ranged between $38.9^{\circ}$ and $42.7^{\circ}$, while the studies by Lund and Langeland resulted in $39.5^{\circ}$ and $37.4^{\circ}$, respectively. Although the localities in these Norwegian studies do not overlap with any samples in this study, as well as not being tested with exactly the same procedure, the results are still quite comparable and substantiate the presented results. Especially the angle of friction from Langeland is near identical to the results from the three closest samples presented here, i.e., nos. 22, 23 and 33 (Table 10).

When incorporating bedrock geology into the results, both similarities and differences among the samples are shown within each rock province and when comparing the provinces to one another. It is well known that the compressive strength of different rock types varies (Afrouz, 1992; Nilsen \& Palmstrøm, 2000; Waltham, 2009). According to the compressive strength description presented in NS-EN ISO 14689-1 (2004), the terms are 'extremely weak' (<1 MPa), 'very weak' (1-5 MPa), 'weak' (5-25 MPa), 'medium strong' (25-50 MPa), 'strong' (50$100 \mathrm{MPa})$, 'very strong' (100-250 MPa) and 'extremely strong' (>250 MPa). Accordingly, the tills are composed of rock types of varying compressive strengths. As initially mentioned, this difference in bedrock geology, including rock strength, should to some extent influence the till shear strength as well. In the following, an evaluation of the results is presented for each individual rock province, including a brief description of the typical rock strengths of the dominant rock type(s) within the respective provinces. Note that the compressive strength values given by Nilsen \& Palmstrøm (2000) are average values from tests on Scandinavian rocks.

\section{Province A/B: extrusive and plutonic rocks / sedimentary rocks in the Oslo region}

When compared to the other provinces, the five samples collected from this province are geographically very close. In addition, the rock types of the respective sites are similar, being mainly dominated by syenite and quartz syenite, as well as granite and granodiorite. Palmstrøm (1997) also presented the compressive strength for several
Norwegian rock types, where syenite varies between 100 and $250 \mathrm{MPa}$. According to Nilsen \& Palmstrøm (2000), the compressive strengths for granite and granodiorite are $169 \mathrm{MPa}$ and $171 \mathrm{MPa}$, respectively, while monzonite has a compressive strength of $106 \mathrm{MPa}$. According to NSEN ISO 14689-1 (2004), these rock types are termed as 'very strong. On the other hand, phyllite and mica schist are listed with compressive strengths of $61 \mathrm{MPa}$ and $71 \mathrm{MPa}$, respectively (Nilsen \& Palmstrøm, 2000), and are termed as 'strong' rocks. However, the compressive strength of both phyllite and mica schist may also be as low as $20 \mathrm{MPa}$ (Palmstrøm, 1997), thereby termed as 'weak' rocks. By solely comparing the compressive strength of these rock types with the till shear test results, in addition to the relatively small geographic area, one should expect intermediate to high shear strength and quite similar results, especially for sample nos. 5, 30 and 31. By comparison, sample no. 6, which contains a significant component of potentially weak mica schist and phyllite, should stand out as the weakest regarding shear strength. The results show a rather intermediate level of average max. shear stresses and angle of friction when compared with the other provinces (Table 15). Actually, the average angle of friction for this province is almost the same as province E. In addition, sample nos. 5,31 and 32 show the most similar results, whereas no. 30 unexpectedly is the weakest due to the low angle of friction and registered shear stresses, even though the rock types are considered stronger than those in no. 6 . This suggests that parameters other than rock (particle) strength may have a larger influence on the results in this particular case.

\section{Province C: Precambrian basement}

The six samples in this province are geographically the most scattered, extending from the southeastern part of Norway close to the Swedish border towards the southwestern part of the country. Various gneisses and granites dominate in five of the samples. According to Nilsen \& Palmstrøm (2000), the compressive strength is $130 \mathrm{MPa}$ for gneiss and $169 \mathrm{MPa}$ for granite. It is important to note, however, that the designation 'gneiss' is used for rocks with potentially large mineralogical differences (Prestvik, 1995). Thus, the compressive strength for gneiss may vary from $80 \mathrm{MPa}$ to $200 \mathrm{MPa}$ (Palmstrøm, 1997). Due to the compressive strengths of these rock types, termed as 'very strong', one should expect a rather high till shear strength. As expected, on average this province scores quite high regarding max. shear stresses and the angle of friction. The average angle of friction is the third highest of all provinces (Table 15). However, the average is affected by the rather low angles of friction from sample nos. 28 and 29. The results show that sample nos. 4, 7, 8 and 9 are quite similar in having a high angle of friction, clearly differing from nos. 28 and 29, which, in turn, are quite similar to one another by having a lower angle of friction. These two southeastern located 
samples are geographically close and relatively similar regarding rock types, but they also have some differences when compared to the remaining four samples. The differences of geography and rock types may partly explain the differences of results. For example, one possible explanation could be the fact that this southeastern region is known for having several mylonite zones, where the rocks have been exposed to both plastic deformation and crushing (Oftedahl, 1981). One cannot exclude that such processes may have influenced these two samples regarding geological parameters such as rock strength and particle size distribution. However, only sample no. 29 seems to lie within such a mylonite zone, and it is also slightly stronger than sample no. 28 , thereby reducing the likelihood that the mylonite zones have affected the material in a way that influenced till shear strength.

\section{Province D: Caledonian rocks, overthrust sheets of Precambrian rocks}

As for province $\mathrm{A} / \mathrm{B}$, the samples from this province are also geographically fairly close. Apart from sample no. 13, which is solely represented by anorthosite, the remaining samples are dominated by mangerite and gabbro, as well as gneiss and amphibolite. Nilsen \& Palmstrøm (2000) list the compressive strength as $248 \mathrm{MPa}$ for gabbro and $107 \mathrm{MPa}$ for amphibolite. However, gabbro may have a compressive strength up to $300 \mathrm{MPa}$ (Palmstrøm, 1997), thus classified as 'extremely strong. Moreover, anorthosite has a compressive strength of $157 \mathrm{MPa}$ (Nilsen \& Palmstrøm, 2000). By only focusing on rock strength, the general till shear strength should be high in this case. As expected, the average max. shear stresses and angle of friction are high. The average angle of friction is higher than for province $\mathrm{C}$ and ranks second of all provinces (Table 15). However, this province has two rather unexpected extremes. While sample nos. 10, 13 and 14 are relatively similar, no. 11 stands out as clearly weaker and no. 12 as clearly stronger. In addition, sample nos. 11 and 12 are geographically close, and they are also quite alike regarding rock types. This difference can hardly be explained by rock strength and, as suggested for province $A / B$, such unexpected results imply that geological parameters other than rock strength may have a larger influence on till shear strength.

\section{Province E: Caledonian rocks, metamorphic and igneous rocks}

The diversities regarding rock types in this province are larger and more complex than any other province, e.g., mica schist, greenstone, phyllite, amphibolite, quartzite, slate and limestone. Therefore, the span of compressive rock strengths differs accordingly, and one would expect a rather greater variety in the shear test results. Quartzite is significantly stronger than phyllite and mica schist, i.e., $172 \mathrm{MPa}$, while greenstone is quite similar to amphibolite with a compressive strength of $105 \mathrm{MPa}$ (Nilsen \& Palmstrøm, 2000). Slate is listed by Waltham (2009) to have an average compressive strength of $90 \mathrm{MPa}$. Limestone has a compressive strength of $74 \mathrm{MPa}$, while mica gneiss is similar to that of slate, i.e., $89 \mathrm{MPa}$ (Nilsen \& Palmstrøm, 2000). Hence, this large variation of rock types and corresponding compressive strengths would imply a variation of the shear test results, but preferably in the intermediate to low levels due to the rather large components of potentially weak mica schist and phyllite. Although the results show intermediate to low levels of average max. shear stresses and angle of friction when compared with the other provinces (Table 15), many of the sample results are actually quite similar, thereby making it difficult to link the individual sample results directly and solely to the associated rock strengths.

\section{Province F: Caledonian rocks, overthrust sheets of sandstone and schist}

The samples in this province are relatively homogeneous regarding rock types. Sandstone is by far the most dominant, with only smaller amounts of other rock types such as conglomerate, quartzite and mica schist represented. Sandstone has a compressive strength of 147 MPa (Nilsen \& Palmstrøm, 2000), although it may vary between $75 \mathrm{MPa}$ and $160 \mathrm{MPa}$ (Palmstrøm, 1997), or even be as low as $30 \mathrm{MPa}$ according to Waltham (2009). Since Norwegian sandstone, which is presumably 'strong' to 'very strong', is dominant in all five samples, this province should show intermediate to high shear strengths and low diversities in the range of results when compared with the other provinces. Although the individual angles of friction and shear stresses are quite similar, the results unexpectedly also show that this province on average has the lowest angle of friction and the lowest max. shear stresses (Table 15). If the till shear strength is to be solely related to the respective rock strengths, the results indicate rock strengths at the lower end of the scale listed by Palmstrøm (1997) or Waltham (2009).

\section{Province G: Caledonian rocks, Precambrian basement, locally affected by the Caledonian orogeny}

This province is also quite homogeneous regarding rock types, where various gneisses are dominant. Even though gneisses may vary significantly in composition (Prestvik, 1995), they are generally regarded as 'strong' to 'very strong' rocks (Nilsen \& Palmstrøm, 2000; Waltham, 2009). As expected, the angles of friction are both high and similar to one another, and, in fact, they are on average the highest measured of all provinces (Table 15). On average, this province also has the highest registered max. shear stresses. However, the two northwesternmost samples (nos. 18 and 19) are noticeably weaker than the three remaining samples, but at the same time quite 
similar to each other. An explanation for this difference is uncertain, but may partly be due to geographical and mineralogical variations of the gneisses.

\section{Summary of discussion}

When analysing and comparing individual samples to one another within their respective provinces, it is rather difficult to establish a clear and direct relationship between the sample strength and their rock type(s), and, especially, to the associated typical rock strength. However, an important uncertainty on this matter is that the listed compressive strength values from the literature are average values, including a significant range, which are not necessarily representative for the samples in this study. On an individual sample level there are some results that do not relate, as one would expect, to bedrock geology and rock strength. Some samples that are dominated by the same rock type(s) and that are geographically close, show both quite different and similar results, e.g., sample nos. 11 and 12, and nos. 16 and 17, respectively. Consequently, and according to the literature, rock (particle) strength cannot be the only parameter influencing till shear strength. As initially mentioned, this implies that other geological parameters are involved, such as particle size distribution and particle shape, which are also known to have an effect on soil shear strength (e.g., Cornforth, 1973; Yagiz, 2001). If the study rather focused on shear testing the samples in a densely packed state, which most likely would introduce dilatancy and the potential of particle crushing, rock strength would possibly be more directly influential. However, on a more generalised level when comparing each of the provinces to one another, there are noticeable differences and a relation to bedrock geology, e.g., in Fig. 7A-C. For the first half of horizontal displacement, the results show that for all three tests the provinces $\mathrm{C}, \mathrm{D}$ and $\mathrm{G}$ are clearly different from $\mathrm{A} / \mathrm{B}, \mathrm{E}$ and $\mathrm{F}$, which are consistently lower regarding shear stresses in the same displacement interval. This difference may be due to the individual province and sample differences regarding the geological parameters, the fraction size limit $(<16$ $\mathrm{mm}$ ), or a combination of these, but it basically seems that provinces $\mathrm{C}, \mathrm{D}$ and $\mathrm{G}$ initially exert more shear resistance than the other three provinces. Such noticeable differences, in turn, may influence the potential of triggering debris slides and flows. The differences, however, are eventually reduced, and the levels of shear stress become more similar towards the end of the displacement. Although the general trend of the shear stress levels of the provinces seems to remain towards the end, the reduction implies that the effect of the different geological parameters in the respective provinces eventually becomes less influential.

Simultaneously, it is necessary to point out the main possible sources of uncertainty regarding the samples. A key aspect to address is that the number of samples may be considered too few to draw a definite conclusion on the levels and differences of shear strength of Norwegian tills, especially with regard to the respective rock provinces. Furthermore, the analysed till samples were independent of their genesis, i.e., no distinction between subglacial till and supraglacial till was made. Another important aspect on this matter is that the changing directions of ice motion and/or climatic fluctuations may have resulted in many tills that are a mixture of glacially eroded rock material and redeposited older sediments (Gillberg, 1977). This is not accounted for, and even if the till material was made solely from erosion of unweathered bedrock material, there is also an unknown variable regarding glacial comminution ('terminal grades') of mineral grains, e.g., between grains from unmetamorphic clastic sedimentary rocks and grains from crystalline rocks. For this example, the latter are to a large extent unstable when subjected to glacial and other mechanical crushing processes (Haldorsen, 1978). Also, due to the relatively passive transport of supraglacial tills, the associated occurrence of comminution is known to be minor (Boulton, 1978). Accordingly, variables such as transport are likely to have influenced both the particle shape and particle size (Clark, 1987), as well as the actual percentage share of different rocktype fragments in the tills. This may especially be the case for samples such as no. 4 in province $C$, consisting of both sandstone and gneiss. It must be emphasised, however, that the given percentage shares of rock types comprising the till samples are only assumed on a theoretical basis. Consequently, the percentage share of the area of rock type(s) surrounding each sample site is based on an approximate measurement and calculation of the bedrock geology map, which is a planar projection not accounting for topography. Although Ehlers (1983) pointed out that different studies (e.g., Perttunen, 1977) have shown that the Scandinavian tills closely reflect the composition of the local bedrock, the bedrock geology can change over short distances, thus introducing significant uncertainty to this theoretical approach. In addition, the ice-flow directions and the chosen maximum transport distance of five kilometres are also simplifications likely to introduce some uncertainty into the results.

\section{Conclusions}

The main shear test performed on 33 near-surface, genetically independent, till samples shows a variation in the registered maximum shear stress up to approximately $16 \%$, whereas the angle of friction varies by $5.5^{\circ}\left(36.0^{\circ}-\right.$ $41.5^{\circ}$ ) with an average of $38.4^{\circ}$. In general, the results differ more in the main test than in the additional tests for repeatability assessment. When observing the comparison of average angles of friction for the different provinces (Table 15), as well as average shear stresses (Fig. 7A-C), a 
clear relation to bedrock geology and rock provinces does appear. This is particularly noticeable in the first half of the horizontal displacement length, where the differences of shear stress are the greatest. The average results show that for all three main tests the provinces C, D and G display higher shear stress and angle of friction than $\mathrm{A} / \mathrm{B}, \mathrm{E}$ and F, which are consistently lower. Generally, provinces of 'strong rocks' have a higher registered shear stress level and angle of friction than provinces of 'weak rocks'. However, these relationships are not so clear on an individual sample level when focusing solely on rock strength, suggesting that rock (particle) strength is not directly the governing parameter of till shear strength. Rock strength would possibly be more influential on the results if the study rather focused on shear testing the till samples in a densely packed state, which most likely would introduce dilatancy and potential particle crushing. For this case, it is considered more likely that rock strength, being a result of variations of rock types throughout the rock provinces, rather indirectly influences till shear strength due to its effect on, e.g., particle shape and size distribution, and, furthermore, that these geological parameters are more directly influential when shear testing the samples in such a loosely packed state. For the last half of horizontal displacement, however, all six provinces show a relatively similar level of average shear stress. Even though the general trend regarding the provinces of high shear stress and low shear stress seems to continue towards the end, it appears that the geological parameters influencing the till shear stress of the respective rock type(s) eventually become less influential.

In summary, due to the noticeable differences of shear stress and angle of friction, especially between the 'strongest province', G, and the 'weakest province', F, this study demonstrates a relation between till shear strength and bedrock geology. Although not conclusive, this suggests that some rock provinces may, solely on the basis of bedrock geology and associated geological parameters, be more prone to debris slides and flows than others. However, it must be emphasised that what makes an area prone to debris slides and flows also depends on many other parameters, i.e., the terrain, hydrological conditions, vegetation, etc. (Chatwin et al., 1994; Bargel et al., 2011). In addition, the number of samples tested is relatively few and they are geographically widely scattered. The samples are also independent of genesis, which is known to influence several of the characteristics of tills, and this is not accounted for. Moreover, the testing procedure and results do not replicate individual field/in situ conditions at the sample sites, as the samples were disturbed when collected and prepared for the purpose of achieving a comparison basis with a minimum of laboratory variables. Hence, the presented results should be regarded as preliminary. For this case, additional testing should be performed if one is to improve the statistical base of the shear strength of Norwegian tills and provide a more thorough evaluation of its relation to bedrock geology.
Acknowledgements. The study is funded by the Norwegian Water Resources and Energy Directorate (NVE project no. 80197), and this article constitutes a part of the author's $\mathrm{PhD}$ degree at the Department of Geoscience and Petroleum at the Norwegian University of Science and Technology (NTNU-IGP). I thank my supervisors at NTNU-IGP, Associate Professor Terje H. Bargel, Professor Bjørge H. Brattli and Associate Professor Randi K. Ramstad for their guidance and helpful comments during the entire process. I thank the now graduated master students at NTNU-IGP, Jørgen M. Langeland, Marte B. Stemland and Marit B. Gjørva, for their assistance during both field and laboratory work. Furthermore, I thank the three reviewers, Senior adviser José M. Cepeda and Director Anders Solheim at the Norwegian Geotechnical Institute (NGI), and an anonymous reviewer, for their valuable suggestions. I also thank Assistant Professor Arnfinn Emdal at NTNU, Department of Civil and Environmental Engineering, Geotechnical Engineering, for helpful comments on the manuscript. Finally, I thank the technical staff at the laboratory, Gunnar Vistnes and Odd Corneliussen, as well as Professor Stephen J. Lippard at NTNU-IGP for proof reading.

\section{References}

Afrouz, A.A. 1992: Practical Handbook of Rock Mass Classification Systems and Modes of Ground Failure. CRC Press, Boca Raton, 208 pp.

Allred, B.J. 2000: Survey of Fractured Glacial Till Geotechnical Characteristics: Hydraulic Conductivity, Consolidation, and Shear Strength. Ohio Journal of Science 100, 63-72.

Andresen, A. 1979: Sampling in moraine, gravel and sand deposits in Norway. Norges Geotekniske Institutt Report 57187-1, 11 pp.

ASTM D3080/D3080M 2011: Standard Test Method for Direct Shear Test of Soils Under Consolidated Drained Conditions. American Society for Testing and Materials, West Conshohocken, 9 pp. https://doi.org/10.1520/D3080_D3080M-11.

Bareither, C.A., Benson, C.H. \& Edil, T.B. 2008a: Reproducibility of Direct Shear Tests Conducted on Granular Backfill Materials. Geotechnical Testing Journal 31,1-11. https://doi.org/10.1520/GTJ100878.

Bareither, C.A., Benson, C.H. \& Edil, T.B. 2008b: Comparison of Shear Strength of Sand Backfills Measured in Small-Scale and LargeScale Direct Shear Tests. Canadian Geotechnical Journal 45, 12241236. https://doi.org/10.1139/T08-058.

Bargel, T.H., Fergus, Å.T., Devoli, G., Orvedal, K., Peerebom, I., Øydvin, E., Stalsberg, K., Sletten, K., Fischer, L., Rubensdotter, L. \& Eilertsen, R. 2011: Plan for skredfarekartlegging: Delrapport jordskred og flomskred (in Norwegian). Norges vassdrags- og energidirektorat Report 16/2011, 46 pp.

Bell, F.G. 2002: The Geotechnical Properties of Some Till Deposits Occuring Along the Coastal Areas of Eastern England. Engineering Geology 63, 49-68.

https://doi.org/10.1016/S0013-7952(01)00068-0.

Bergersen, O.F. \& Garnes, K. 1971: Evidence of Sub-Till Sediments from a Weichselian Interstadial in the Gudbrandsdalen Valley, Central East Norway. Norwegian Journal of Geography 25, 98-107. https://doi.org/10.1080/00291957108551915.

Bergersen, O.F. \& Garnes, K. 1972: Ice Movements and Till Stratigraphy in the Gudbrandsdal Area. Preliminary Results. Norwegian Journal of Geography 26, 1-16. https://doi.org/10.1080/00291957208621936.

Bishop, A.W. \& Eldin, G. 1950: Undrained Triaxial Tests on Saturated Sands and Their Significance in the General Theory of Shear Strength. Géotechnique 2, 13-32.

https://doi.org/10.1680/geot.1950.2.1.13. 
Bjerrum, L. \& Landva, A. 1966: Direct Simple-Shear Tests on a Norwegian Quick Clay. Géotechnique 16, 1-20.

https://doi.org/10.1680/geot.1966.16.1.1.

Boje, S., Colleuille, H. \& Devoli, G. 2014: Terskelstudier for utløsning av jordskred i Norge: Oppsummering av hydrometeorologiske terskelstudier ved NVE i perioden 2009 til 2013 (in Norwegian). Norges vassdrags- og energidirektorat Report 43-2014, 56 pp.

Bolton, M.D. 1986: The strength and dilatancy of sands. Géotechnique 36, 65-78. https://doi.org/10.1680/geot.1986.36.1.65.

Boulton, G.S. 1974: Processes and Patterns of Glacial Erosion. In Coates, D.R. (ed.): Glacial Geomorphology: A proceedings volume of the Fifth Annual Geomorphology Symposia Series, held at Binghamton, New York, September 26-28, 1974, pp. 41-88.

Boulton, G.S. 1978: Boulder shapes and grain-size distributions of debris as indicators of transport paths through a glacier and till genesis. Sedimentology 25, 773-799.

https://doi.org/10.1111/j.1365-3091.1978.tb00329.x.

Boulton, G.S. \& Paul, M.A. 1976: The Influence of Genetic Processes on Some Geotechnical Properties of Glacial Tills. Quarterly Journal of Engineering Geology 9, 159-194.

https://doi.org/10.1144/GSL.QJEG.1976.009.03.03.

BS 1377-7 1990: Methods of test for soils for civil engineering purposes - Part 7: Shear strength tests (total stress). British Standards Institution, London, $62 \mathrm{pp}$.

Budhu, M. 2015: Soil mechanics fundamentals: Imperial version. John Wiley \& Sons, Chichester, 376 pp.

Cammeraat, E. \& Rappol, M. 1987: On the Relationship of Bedrock Lithology and Grain Size Distribution of Till in Western Allgäu (West Germany) and Vorarlberg (Austria). Jahrbuch der Geologischen Bundesanstalt 130, 383-389.

Chatwin, S.C., Howes, D.E., Schwab, J.W. \& Swanston, D.N. 1994: Land Management Handbook 18: A guide for management of landslideprone terrain in the Pacific Northwest, $2^{\text {nd }}$ edition. B.C. Ministry of Forests, Victoria, B.C., 220 pp.

Clark, P.U. 1987: Subglacial Sediment Dispersal and Till Composition. Journal of Geology 95, 527-541. https://doi.org/10.1086/629147.

Clarke, G.K.C. 1987: Subglacial Till: A Physical Framework for Its Properties and Processes. Journal of Geophysical Research 92, 90239036. https://doi.org/10.1029/JB092iB09p09023.

Converse, F.J. 1953: The Use of the Direct Shearing Testing Machine in Foundation Engineering Practice. In Tschebotarioff, G. (ed.): Symposium on Direct Shear Testing of Soils, pp. 75-87. https://doi.org/10.1520/STP47726S.

Cornforth, D.H. 1973: Prediction of Drained Strength of Sands from Relative Density Measurements. In Selig, E.T. \& Ladd, R.S. (eds.): Evaluation of Relative Density and its Role in Geotechnical Projects Involving Cohesionless Soils, ASTM Special Technical Publication 523, pp. 281-303. https://doi.org/10.1520/STP37878S.

Cuffey, K.M. \& Paterson, W.S.B. 2010: The Physics of Glaciers, $4^{\text {th }}$ edition. Elsevier, Burlington, 704 pp.

Das, B.M. 2010: Principles of Geotechnical Engineering, $25^{\text {th }}$ Anniversary edition, $7^{\text {th }}$ edition. Cengage Learning, Stamford, $683 \mathrm{pp}$.

Dearman, W.R. 1991: Engineering Geological Mapping. ButterworthHeinemann, Oxford, 387 pp.

Donald, I.B. 1956: Shear Strength Measurements in Unsaturated Noncohesive Soils with Negative Pore Pressures. Proceedings of the $2^{\text {nd }}$ Australia and New Zealand Conference on Soil Mechanics and Foundation Engineering, 1956, Christchurch, New Zealand, pp. 200 205.
Dreimanis, A. 1976: Tills: Their Origin and Properties. In Legget, R.F. (ed.): Glacial Till: An Inter-disciplinary Study, Royal Society of Canada Special publication 12, pp. 11-49.

Dreimanis, A. \& Vagners, U.J. 1971: Bimodal Distribution of Rock and Mineral Fragments in Basal Tills. In Goldthwait, R.P. (ed.): Till/ a Symposium, pp. 237-250.

Dreimanis, A., Reavely, G.H., Cook, R.J.B., Knox, K.S. \& Moretti, F.J. 1957: Heavy mineral studies in tills of Ontario and adjacent areas. Journal of Sedimentary Petrology 27, 148-161.

https://doi.org/10.1306/74D70687-2B21-11D7-8648000102C1865D.

Duncan, J.M., Wright, S.G. \& Brandon, T.L. 2014: Soil Strength and Slope Stability, $2^{\text {nd }}$ edition. Wiley, Hoboken, $317 \mathrm{pp}$.

Ehlers, J. 1983: Different till types in North Germany and their origin. In Evenson, E.B., Schlüchter, Ch. \& Rabassa, J. (eds.): Tills and Related Deposits, Balkema, Rotterdam, pp. 61-80.

Fannin, R.J., Eliandorani, A. \& Wilkinson, J.M.T. 2005: Shear strength of cohesionless soils at low stress. Géotechnique 55, 467-478. https://doi.org/10.1680/geot.2005.55.6.467.

Feda, J. 2002: Notes on the effect of grain crushing on the granular soil behavior. Engineering Geology 63, 93-98.

https://doi.org/10.1016/S0013-7952(01)00072-2.

Fredlund, D.G. \& Rahardjo, H. 1993: Soil Mechanics for Unsaturated Soils. John Wiley \& Sons, New York, 517 pp.

https://doi.org/10.1002/9780470172759.

Fredlund, D.G., Xing, A., Fredlund, M.D. \& Barbour, S.L. 1996: The relationship of the unsaturated soil shear strength to the soil-water characteristic curve. Canadian Geotechnical Journal 33, 440-448. https://doi.org/10.1139/t96-065.

Gan, J.K.M., Fredlund, D.G. \& Rahardjo, H. 1988: Determination of the shear strength parameters of an unsaturated soil using the direct shear test. Canadian Geotechnical Journal 25, 500-510. https://doi.org/10.1139/t88-055.

Garnes, K. 1973: Till Studies in the Gudbrandsdal Area, Eastern Central Norway. Bulletin of the Geological Institutions of the University of Uppsala 5, 81-92.

Gillberg, G. 1977: Redeposition: A process in till formation. Geologiska Föreningen i Stockholm Förhandlingar 99, 246-253.

https://doi.org/10.1080/11035897709455019.

Grimstad, E., Dahl, F.E.B. \& Jakobsen, P.D. 2007: Norsk kompetanse på geologiske materialers slitasjeegenskaper (in Norwegian). Byggeindustrien 39, 74 pp.

Haldorsen, S. 1978: Glacial comminution of mineral grains. Norsk Geologisk Tidsskrift 58, 241-243.

Haldorsen, S. 1982: The genesis of tills from Åstadalen, southeastern Norway. Norsk Geologisk Tidsskrift 62, 17-38.

Haldorsen, S. \& Krüger, J. 1990: Till Genesis and Hydrogeological Properties. Nordic Hydrology 21, 81-94.

Haldorsen, S., Jenssen, P.D., Koler, J.C. \& Myhr, E. 1983: Some hydraulic properties of Sandy-silty Norwegian Tills. Acta Geologica Hispanica 18, 191-198.

Hattamleh, O.A., Faisal, A., Qablan, H.A. \& Al-Rousan, T. 2010: Effect of grain crushing and bedding plane inclination on Aqaba sand behavior. Bulletin of Engineering Geology and the Environment 69, 41-49. https://doi.org/10.1007/s10064-009-0238-6.

Haugen, M. \& Lindgård, J. 2012: Tilslagsmaterialer for betong (in Norwegian). SINTEF Byggforsk Report 572.115, 8 pp.

Hencher, S. 2012: Practical Engineering Geology. Spon Press, London, 450 pp. https://doi.org/10.1201/b12836. 
Hooke, R.L. 2005: Principles of Glacier Mechanics, $2^{\text {nd }}$ edition. Cambridge University Press, Cambridge, 448 pp. https://doi.org/10.1017/CBO9780511614231.

Hungr, O., McDougall, S. \& Bovis, M. 2005: Entrainment of material by debris flows. In Jakob, M. \& Hungr, O. (eds.): Debris-flow Hazards and Related Phenomena, pp. 135-158.

https://doi.org/10.1007/b138657.

Ishibashi, I. \& Hazarika, H. 2015: Soil Mechanics Fundamentals and Applications, $2^{\text {nd }}$ edition. CRC Press, London, $432 \mathrm{pp}$.

ISO 17892-10 2004: Geotechnical investigation and testing: Laboratory testing of soil: Part 10: Direct shear tests. International Organization for Standardization, Geneva, $12 \mathrm{pp}$.

ISO 17892-1 2014: Geotechnical investigation and testing: Laboratory testing of soil: Part 1: Determination of water content. International Organization for Standardization, Geneva, $10 \mathrm{pp}$.

Iverson, N.R., Jansson, P. \& Hooke, R.L. 1994: In-situ measurement of the strength of deforming subglacial till. Journal of Glaciology 40, 497-503. https://doi.org/10.1016/0148-9062(95)97280-V.

Jaedicke, C., Solheim, A., Blikra, L.H., Stalsberg, K., Sorteberg, A., Aaheim, A., Kronholm, K., Vikhamar-Schuler, D., Isaksen, K., Sletten, K., Kristensen, K., Barstad, I., Melchiorre, C., Høydal, Ø.A. \& Mestl, H. 2008: Spatial and temporal variations of Norwegian geohazards in a changing climate, the GeoExtreme Project. Natural Hazards Earth System Sciences 8, 893-904.

https://doi.org/10.5194/nhess-8-893-2008.

Johnsen, S.O. 1995: Norges berggrunn (in Norwegian). In Prestvik, T., Johnsen, S.O., Rueslåtten, H.G. \& Moseid, T. (eds.): Videregående geologi, Vett \& Viten, Stabekk, pp. 93-107.

Kaniraj, S.R. 1988: Design aids in soil mechanics and foundation engineering. Tata McGraw-Hill, New Delhi, 698 pp.

Koloski, J.W., Schwarz, S.D. \& Tubbs, D.W. 1989: Geotechnical Properties of Geologic Materials. In Galster, R.W. (ed.): Engineering Geology in Washington, Washington Division of Geology and Earth Resources Bulletin 78, pp. 19-26.

Kronholm, K., Jaedicke, C., Sletten, K. \& Stalsberg, K. 2007: Endring i hyppighet av skred: vil faren for ulike typer skred øke? (in Norwegian). In Førland, E.J., Amundsen, H. \& Hovelsrud, G.K. (eds.): Utviklingen av naturulykker som følge av klimaendringer: Utredning på oppdrag fra Statens Landsbruksforvaltning, pp. 33-37.

Langeland, J.M. 2016: Lausmasseskred $i$ finkorna avsetningar: Kartlegging av fare for jord- og flaumskred i Soknedal, Midtre Gauldal kommune (in Norwegian). MSc thesis, the Norwegian University of Science and Technology, $148 \mathrm{pp}$.

Langåker, М.Ø. 2014: Joberget tunnel: Engineering geological aspects of soil tunneling based on the Pipe Umbrella method. Specialization project, the Norwegian University of Science and Technology, 50 pp.

Lommler, J.C. 2012: Geotechnical Problem Solving. John Wiley \& Sons, Chichester, 349 pp. https://doi.org/10.1002/9781119968429.

Lund, M.R. 2013: En studie av skredaktiviteten i Arnegårdslia, Nes kommune, Hallingdal: Utløsende årsaker og menneskelig påvirkning (in Norwegian). MSc thesis, University of Oslo, 72 pp.

Låg, J. 1948: Studies on the parent material of the morainic covers of the south-eastern part of Norway (in Norwegian), Meddelelser fra Det norske skogsforsøksvesen 10, 1-223.

Miller, G.A. \& Hamid, T.B. 2007: Interface Direct Shear Testing of Unsaturated Soil. Geotechnical Testing Journal 30, 1-10.

https://doi.org/10.1520/GTJ13301.
Milligan, V. 1976: Geotechnical Aspects of Glacial Tills. In Legget, R.F. (ed.): Glacial Till: An Inter-diciplinary Study, Royal Society of Canada Special publication 12, pp. 269-291.

NGU 2016a: Bedrock geology. https://www.ngu.no/en/topic/bedrock-geology-0 (accessed 13.09.2016).

NGU 2016b: Online map service: Bedrock geology N250 (scale 1:250,000).

http://geo.ngu.no/kart/berggrunn/ (accessed 12.08.2016).

NGU 2016c: Online map service: Quaternary geology. http://geo.ngu.no/kart/losmasse/ (accessed 12.08.2016).

Nilsen, B. \& Palmstrøm, A. 2000: Engineering geology and rock engineering: Handbook No 2. Norwegian Group for Rock Mechanics, Oslo, 249 pp.

Norem, H. \& Sandersen, F. 2014: Flom- og sørpeskred: Håndbok V139 (in Norwegian). The Norwegian Public Roads Administration, Oslo, 103 pp.

NS-EN 932-1 1996: Tests for general properties of aggregates - Part 1: Methods for sampling. Standard Norge, Lysaker, $27 \mathrm{pp}$.

NS-EN 932-2 1999: Prøvingsmetoder for generelle egenskaper for tilslag: Del 2: Metoder for deling av laboratorieprøver (in Norwegian). Standard Norge, Lysaker, $16 \mathrm{pp}$.

NS-EN 933-1 2012: Prøvingsmetoder for geometriske egenskaper for tilslag: Del 1: Bestemmelse av Kornstørrelsesfordeling: Sikteanalyse (in Norwegian). Standard Norge, Lysaker, 10 pp.

NS-EN ISO 14689-1 2004: Geotechnical investigation and testing: Identification and classification of rock: Part 1: Identification and description (ISO 14689-1:2003). Standard Norge, Lysaker, 16 pp.

NVE 2013: Om jordskredvarslingen (in Norwegian). http://www.varsom.no/flom-og-jordskredvarsling/ om-flomvarslingen-og-jordskredvarslingen/ (accessed 08.06.2016).

NVE 2016: Flaum og skred (in Norwegian). https://www.nve.no/flaum-og-skred/ (accessed 07.06.2016).

Oftedahl, C. 1981: Norges geologi: En oversikt over Norges regionalgeologi, $2^{\text {nd }}$ edition (in Norwegian). Tapir, Trondheim, 207 pp.

Olsen, L., Sveian, H., Ottesen, D. \& Rise, L. 2013: Quaternary glacial, interglacial and interstadial deposits of Norway and adjacent onshore and offshore areas. In Olsen, L., Fredin, O. \& Olesen, O. (eds.): Quaternary Geology of Norway, Geological Survey of Norway Special publication 13, pp. 79-144.

Ottesen, D., Dowdeswell, J.A. \& Rise, L. 2005: Submarine landforms and the reconstruction of fast-flowing ice streams within a large Quaternary ice sheet: The 2500-km-long Norwegian-Svalbard margin $\left(57^{\circ}-80^{\circ} \mathrm{N}\right)$. Geological Society of America Bulletin 117, 1033-1050. https://doi.org/10.1130/B25577.1.

Palmeira, E.M. 1987: The study of soil reinforcement interaction by means of large scale laboratory tests. $\mathrm{PhD}$ thesis, University of Oxford, $222 \mathrm{pp}$.

Palmstrøm, A. 1997: Kurs i fjell-leere, en kort innføring i ingeniørgeologi (in Norwegian). Berdal Strømme, 48 pp.

Perttunen, M. 1977: The lithologic relation between till and bedrock in the region of Hämeenlinna, southern Finland. Geological Survey of Finland Bulletin 291, 68 pp.

Prestvik, T. 1995: Bergarter (in Norwegian). In Prestvik, T., Johnsen, S.O., Rueslåtten, H.G. \& Moseid, T. (eds.): Videregående geologi, Vett \& Viten, Stabekk, pp. 40-85. 
Rahardjo, H., Lim, T.T., Chang, M.F. \& Fredlund, D.G. 1995: Shearstrength characteristics of a residual soil. Canadian Geotechnical Journal 32, 60-77. https://doi.org/10.1016/0148-9062(96)87452-3.

Rathbun, A.P., Marone, C., Alley, R.B. \& Anandakrishnan, S. 2008: Laboratory study of the frictional rheology of sheared till. Journal of Geophysical Research 133, 14 pp.

https://doi.org/10.1029/2007JF000815.

Reite, A.J. 1990: Sør-Trøndelag. Quaternary geological map, scale 1:250,000 with description (in Norwegian), Norges geologiske undersøkelse Skrifter 96, 1-39.

Reite, A.J. 1994: Weichselian and Holocene geology of Sør-Trøndelag and adjacent parts of Nord-Trøndelag county, Central Norway. Norges geologiske undersøkelse Bulletin 426, 1-30.

Sandersen, F. 2014: Løsmasse- og flomskred (in Norwegian). In Høeg, K., Karlsrud, K. \& Lied, K. (eds.): Skred: Skredfare og sikringstiltak: praktiske erfaringer og teoretiske prinsipper, Universitetsforlaget, Oslo, pp. 77-93.

Schnellmann, R., Rahardjo, H. \& Schneider, H.R. 2013: Unsaturated shear strength of a silty sand. Engineering Geology 162, 88-96. https://doi.org/10.1016/j.enggeo.2013.05.011.

Simoni, A. \& Houlsby, G.T. 2006: The direct shear strength and dilatancy of sand-gravel mixtures. Geotechnical and Geological Engineering 24, 523-549.

https://doi.org/10.1007/s10706-004-5832-6.

Skuodis, Š. \& Tamošiūnas, T. 2014: Direct Shear Tests with Evaluation of Variable Shearing Area. Science: Future of Lithuania 6, 499-503. https://doi.org/10.3846/mla.2014.692.

Smith, I. 2014: Smith's Elements of Soil Mechanics, $9^{\text {th }}$ edition. Wiley, Somerset, $488 \mathrm{pp}$.

Testconsult 2012: SB2010 Operation manual SB2010 Automatic Large Scale Shearbox. Testconsult Limited, Warrington, 22 pp.

Thermann, K., Gau, C. \& Tiedemann, J. 2006: Shear strength parameters from direct shear tests: influencing factors and their significance. IAEG2006 484, 1-12.

Thoresen, M.K. 2000: Kvartoergeologisk kart over Norge, Tema: Jordarter, $2^{\text {nd }}$ edition (in Norwegian). Geological Survey of Norway, Trondheim, $64 \mathrm{pp}$.

Vanapalli, S.K., Fredlund, D.G. \& Pufahl, D.E. 1996: The Relationship Between the Soil-Water Characteristic Curve and the Unsaturated Shear Strength of a Compacted Glacial Till. Geotechnical Testing Journal 19, 259-268. https://doi.org/10.1520/GTJ10351J.

Vorren, T.O. 1977: Weichselian ice movement in South Norway and adjacent areas. Boreas 6, 247-257. https://doi.org/10.1111/j.1502-3885.1977.tb00292.x.

Vorren, T.O. \& Mangerud, J. 2006: Istider kommer og går (in Norwegian). In Ramberg, I.B., Bryhni, I. \& Nøttvedt, A. (eds.): Landet blir til: Norges geologi, Norsk Geologisk Forening, Trondheim, pp. 478-531.

Waltham, T. 2009: Foundations of Engineering Geology, $3^{\text {rd }}$ edition. Spon Press, London, $98 \mathrm{pp}$.

Yagiz, S. 2001: Brief note on the influence of shape and percentage of gravel on the shear strength of sand and gravel mixtures. Bulletin of Engineering Geology and the Environment 60, 321-323.

https://doi.org/10.1007/s100640100122. 